\title{
Neutronics and Thermal Hydraulics Study for Using a Low-Enriched Uranium Core in the Advanced Test Reactor -- 2008 Final Report
}

G. S. Chang

M.A. Lillo

R. G. Ambrosek

June 2008

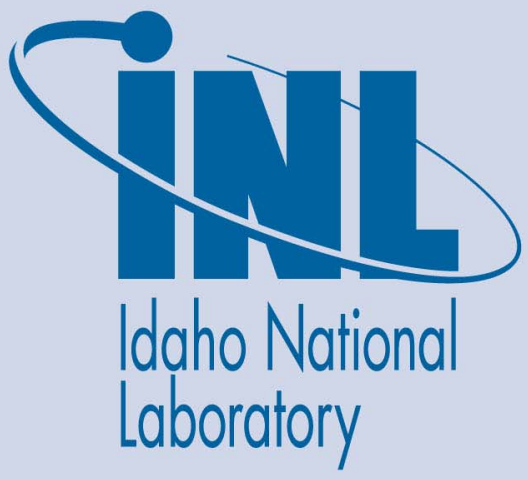

The INL is a U.S. Department of Energy National Laboratory operated by Battelle Energy Alliance 
INL/EXT-08-13980

\title{
Neutronics and Thermal Hydraulics Study for Using a Low-Enriched Uranium Core in the Advanced Test Reactor 2008 Final Report
}

\author{
G. S. Chang \\ M. A. Lillo \\ R. G. Ambrosek \\ June 2008 \\ Idaho National Laboratory \\ Idaho Falls, Idaho 83415 \\ Prepared for the \\ U.S. Department of Energy \\ Office of National Nuclear Security Administration \\ Under DOE Idaho Operations Office \\ Contract DE-AC07-05ID14517
}




\title{
Neutronics and Thermal Hydraulics Study for Using a \\ Low-Enriched Uranium Core \\ in the \\ Advanced Test Reactor \\ 2008 Final Report
}

\author{
INL/EXT-08-13980
}

June 2008

Approved by

Type 1st persons name here

Date

Type 2nd persons name here

Date

Type 3rd persons name here

Date 


\section{ABSTRACT}

The Advanced Test Reactor (ATR) is a high power density and high neutron flux research reactor operating in the United States. Powered with highly enriched uranium (HEU), the ATR has a maximum thermal power rating of $250 \mathrm{MWth}$. Because of the large test volumes located in high flux areas, the ATR is an ideal candidate for assessing the feasibility of converting an HEU driven reactor to a lowenriched core. The present work investigates the necessary modifications and evaluates the subsequent operating effects of this conversion.

A detailed plate-by-plate MCNP ATR 1/8th core model was developed and validated for a fuel cycle burnup comparison analysis. Using the current HEU U-235 enrichment of $93.0 \%$ as a baseline, an analysis was performed to determine the lowenriched uranium (LEU) density and U-235 enrichment required in the fuel meat to yield an equivalent K-eff versus effective full power days (EFPDs) between the HEU and the LEU cores. The MCNP ATR 1/8th core model was used to optimize the U-235 loading in the LEU core, such that the differences in K-eff and heat flux profiles between the HEU and LEU cores were minimized.

The depletion methodology MCWO was used to calculate K-eff versus EFPDs in this paper. The MCWO-calculated results for the LEU demonstrated adequate excess reactivity such that the K-eff versus EFPDs plot is similar to the ATR reference HEU case study. Each HEU fuel element contains 19 fuel plates with a fuel meat thickness of $0.508 \mathrm{~mm}$ (20 mil). In this work, the proposed LEU (U-10Mo) core conversion case with nominal fuel meat thickness of $0.330 \mathrm{~mm}$ (13 mil) and U-235 enrichment of $19.7 \mathrm{wt} \%$ is used to optimize the radial heat flux profile by varying the fuel meat thickness from $0.191 \mathrm{~mm}(7.0 \mathrm{mil})$ to $0.330 \mathrm{~mm}(13.0 \mathrm{mil})$ at the inner 4 fuel plates (1-4) and outer 4 fuel plates (16-19). A $0.8 \mathrm{~g}$ of Boron-10, a burnable absorber, was added in the inner and outer plates to reduce the initial excess reactivity, and the peak to average ratio of the inner/outer heat flux more effectively. Because the B-10 (n, $\alpha)$ reaction will produce Helium-4 (He-4), which might degrade the LEU foil type fuel performance, an alternative absorber option is proposed. The

proposed LEU case study will have $6.918 \mathrm{~g}$ of Cadmium $(\mathrm{Cd})$ mixed with the LEU at the inner 4 fuel plates (1-4) and outer 4 fuel plates (16-19) as a burnable absorber to achieve peak to average ratios similar to those for the ATR reference HEU case study. 


\section{CONTENTS}

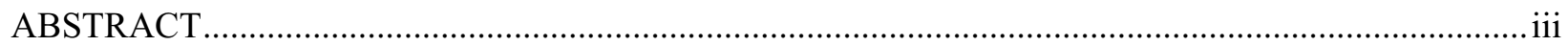

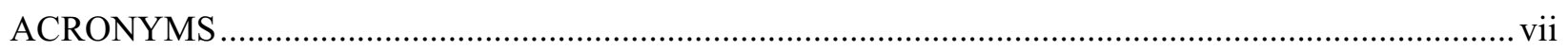

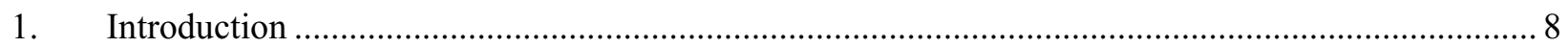

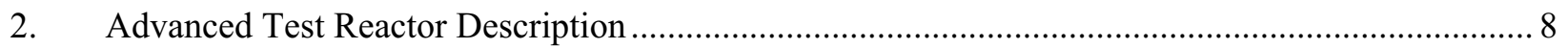

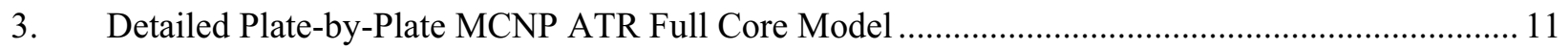

3.1 Validation of the Plate-by-Plate MCNP ATR Full Core Model.......................................... 12

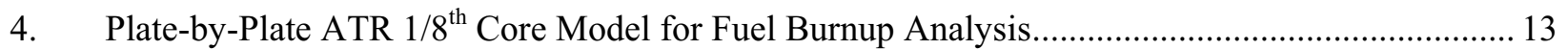

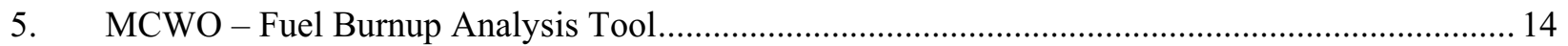

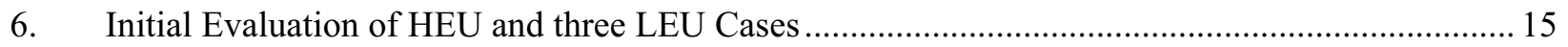

6.1 Comparison of K-eff versus EFPDs for ATR Reference HEU (Case-A) and Un-optimized

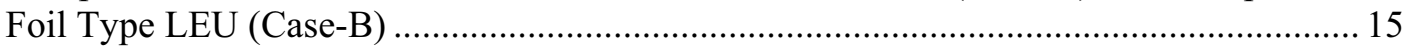

6.2 Comparison of Radial Fission Power Profiles at BOC for ATR Reference HEU and Un-

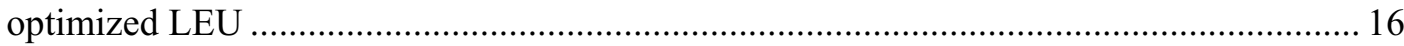

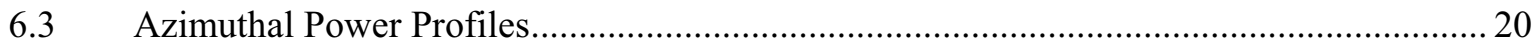

7. Evaluation of HEU and Optimized LEU Fuel Cycle Performance ............................................. 22

7.1 Optimized LEU Radial Fission Power Profile at BOC …................................................ 22

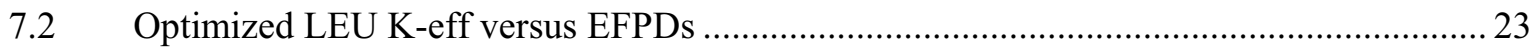

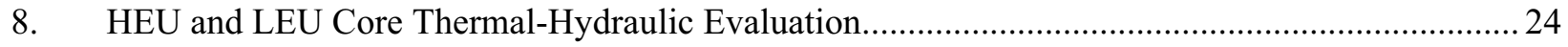

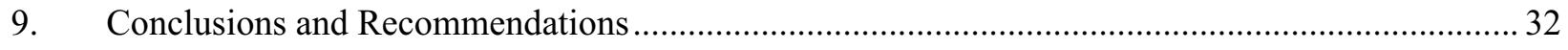

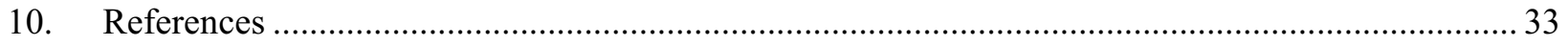




\section{FIGURES}

Figure 1. ATR Core Configuration Cross Sectional Diagram (Nine flux traps and 68 Irradiation

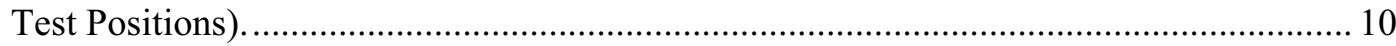

Figure 2. ATR MCNP full core model with 19 fuel plates per FE.................................................. 11

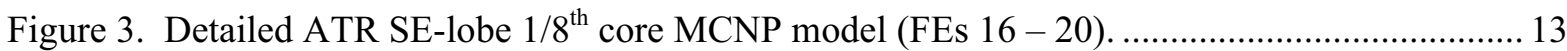

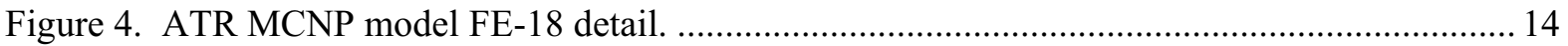

Figure 5. K-eff vs. EFPDs for ATR reference HEU Case-A and un-optimized LEU Case-B........... 16

Figure 6. Radial fission power heat flux L2AR for ATR reference HEU Case-A, and un-

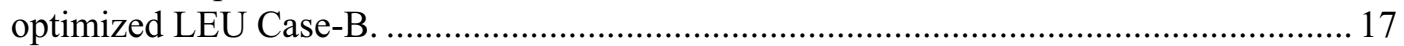

Figure 7. FE-18 Azimuthal distribution of fission power density L2AR...................................... 21

Figure 8. FE-18 Axial Distribution of fission power density L2AR............................................. 21

Figure 9. Fission power heat flux L2AR radial profiles for HEU Case-A and optimized LEU

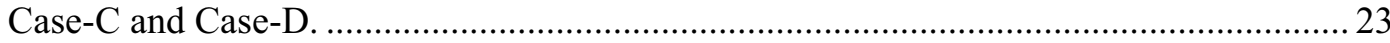

Figure 10. MCWO-calculated K-eff versus EFPDs for ATR reference HEU Case-A and

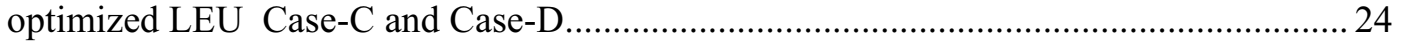

Figure 11. Temperature in LEU Plate 3 for Condition 4 Reactivity Insertion .................................. 26

Figure 12. Temperature in LEU Plate 15 for Condition 4 Reactivity Insertion ................................26

Figure 13. Temperature in LEU Plate 16 for Condition 4 Reactivity Insertion ................................ 27

Figure 14. Temperature in LEU Plate 17 for Condition 4 Reactivity Insertion ............................... 27

Figure 15. Temperature in LEU Plate 19 for Condition 4 Reactivity Insertion ............................... 28

Figure 16.. Temperature in HEU Plate 3 for Condition 4 Reactivity Insertion ...................................28

Figure 17. Temperature in HEU Plate 15 for Condition 4 Reactivity Insertion................................29

Figure 18. Temperature in HEU Plate 16 for Condition 4 Reactivity Insertion................................29

Figure 19. Temperature in HEU Plate 17 for Condition 4 Reactivity Insertion..................................30

Figure 20. Temperature in HEU Plate 19 for Condition 4 Reactivity Insertion................................. 30

Figure 21. Temperature in Coolant Channel 16 for LEU Fuel, Steady State ..................................... 31

Figure 22. Temperature in Coolant Channel 17 for HEU Fuel, Steady State .................................... 31 


\section{TABLES}

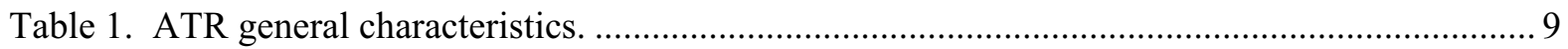

Table 2. ATR Cycle 134A ASUDAS (as-run) initial critical conditions. ........................................ 12

Table 3. Initial critical conditions for ATR Cycle 134A (MCNP, PDQWS, and ASUDAS). ............ 12

Table 4. Specifications for a ATR reference HEU (U-235 93.5wt\%) FE with B-10 in the 4

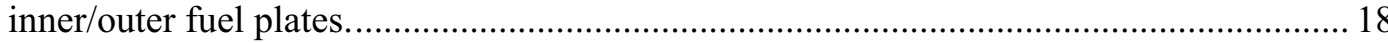

Table 5. Specifications for the optimized LEU (U-235 19.7wt\%) FE with B-10 in the 4 inner/outer fuel plates

Table 6. Specifications for the optimized LEU (U-235 19.7wt\%) FE with Cd in the 4 inner/outer fuel plates.

Table A-1. ATR standard HEU fuel assembly radial power profile (0.66g B-10 in inner/outer 4 plates).

Table A-2. Optimized LEU (Case-C) U-10Mo fuel assembly radial power profile with $0.8 \mathrm{~g}$ of B10 in inner/outer 4 plates (Optimized with fixed $19.7 \mathrm{wt} \%$ U-235 and varying fuel meat thickness).

Table A-3. Optimized LEU U-10Mo fuel assembly radial power profile with $6.918 \mathrm{~g}$ of Cd in inner/outer 4 plates.

Table A-4. Averaged fuel azimuthal fission power density local to average ratio (L2AR).

Table A-5. FE-18 Axial local to average ratio. 


\section{ACRONYMS}

ASUDAS ATR Surveillance Data System

ATR Advanced Test Reactor

BOC beginning of cycle

C center

DNB departure from nucleate boiling

DOE Department of Energy

EFPD Effective Full Power Day

FE fuel element

FI flow instability

HEU highly enriched uranium

INL Idaho National Laboratory

L2AR local-to-average-ratio

LbyL lobe-by-lobe

LEU low-enriched uranium

MCWO Monte Carlo with ORIGEN2

MW megawatt

NE northeast

NW northwest

OSCC Outer Shim Control Cylinder

RERTR reduced enrichment for research and test reactors

SE southeast

SW southwest

TSR technical safety requirement

UFSAR upgraded final safety analysis report 


\section{Neutronics and Thermal Hydraulics Study for Using a Low-Enriched Uranium Core in the Advanced Test Reactor 2008 Final Report}

\section{Introduction}

The Advanced Test Reactor (ATR) at the Idaho National Laboratory (INL) is a high power density and high neutron flux research reactor operating in the United States. Powered with highly enriched uranium (HEU), the ATR has a maximum thermal power rating of $250 \mathrm{MW}$ th with a maximum unperturbed thermal neutron flux rating of $1.0 \times 10^{15} \mathrm{n} / \mathrm{cm}^{2}-\mathrm{s}$. The conversion of nuclear test reactors currently fueled with HEU to operate with low-enriched uranium (LEU) is being addressed by the reduced enrichment for research and test reactors (RERTR) program. The ATR is a representative candidate for assessing the necessary modifications and evaluating the subsequent operating effects encountered when converting from HEU to LEU fuel.

The scope of this task is to assess the feasibility of converting the ATR HEU fuel to LEU fuel while retaining all key functional and safety characteristics of the reactor. Using the current HEU U-235 enrichment of $93.0 \%$ as a baseline, this study will evaluate the LEU uranium density required in the fuel meat to yield an equivalent K-eff between the ATR HEU core and an LEU core after 125 effective full power days (EFPDs) of operation with a total core power of $115 \mathrm{MW}$. A lobe power of $23 \mathrm{MW}$ is assumed for each of the five lobes. Then, the LEU U-235 loading that yields an equivalent K-eff as the HEU U-235 loading will be used to predict radial, axial, and azimuthal power distributions. The heat rate distributions will also be evaluated for this core and used to predict the core performance as it relates to the current Upgraded Final Safety Analysis Report (UFSAR) and the associated Technical Safety Requirements (TSR's).

\section{Advanced Test Reactor Description}

The ATR was originally commissioned in 1967 with the primary mission of materials and fuels testing for the United States Naval Reactors Program. The ATR is a high power density and high neutron flux research reactor with large test volumes in high flux regions. General characteristics for the ATR are listed in Table 1. Powered with HEU, the ATR has a maximum thermal power rating of $250 \mathrm{MW}$ th with a maximum unperturbed thermal neutron flux rating of $1.0 \times 10^{15} \mathrm{n} / \mathrm{cm}^{2}-\mathrm{s}$.

The ATR was designed to provide large-volume, high-flux test locations. The unique serpentine fuel arrangement (Figure 1) provides nine high-intensity neutron flux traps and 68 additional irradiation positions inside the reactor core reflector tank, each of which can contain multiple experiments.

The ATR's unique control device design permits large power shifts among the nine flux traps. The ATR uses a combination of control cylinders or drums and neck shim rods (Figure 1). The control cylinders rotate hafnium plates toward and away from the core, and the shim rods, which withdraw vertically, are individually inserted or withdrawn to adjust power. Within bounds, the power level in each corner lobe of the reactor can be controlled independently. 
Table 1. ATR general characteristics.

\begin{tabular}{|c|c|}
\hline Reactor Parameter & $\underline{\text { Value }}$ \\
\hline Thermal Power & $250 \mathrm{MW}_{\mathrm{th}}^{\mathrm{a}}$ \\
\hline Power Density & $1.0 \mathrm{MW} / \mathrm{L}$ \\
\hline Maximum Thermal Neutron Flux & $1.0 \times 10^{15} \mathrm{n} / \mathrm{cm}^{2}-\mathrm{s}^{\mathrm{b}}$ \\
\hline Maximum Fast Flux & $5.0 \times 10^{14} \mathrm{n} / \mathrm{cm}^{2}-\mathrm{s}^{\mathrm{b}}$ \\
\hline Number of Flux Traps & 9 \\
\hline Number of Experiment Positions & $68^{\mathrm{c}}$ \\
\hline Core Parameter & $\underline{\text { Value }}$ \\
\hline Number of Fuel Assemblies & 40 \\
\hline Active Length of Assemblies & $1.2 \mathrm{~m}(4 \mathrm{ft})$ \\
\hline Number of Fuel Plates per Assembly & 19 \\
\hline Uranium-235 Content of an Assembly & $1,075 \mathrm{~g}$ \\
\hline Total Core Fresh Fuel Load & $43 \mathrm{~kg}$ \\
\hline Coolant Parameter & $\underline{\text { Value }}$ \\
\hline Design Pressure & $0.7 \mathrm{MPa}$ (390 psig) \\
\hline Design Temperature & $115^{\circ} \mathrm{C}\left(240^{\circ} \mathrm{F}\right)$ \\
\hline Reactor Coolant & Light Water \\
\hline Maximum Coolant Flow Rate & $3.09 \mathrm{~m}^{3} / \mathrm{s}(49,000 \mathrm{gpm})$ \\
\hline Coolant Temperature, Inlet (Operating) & $<52^{\circ} \mathrm{C}\left(125^{\circ} \mathrm{F}\right)$ inlet \\
\hline Coolant Temperature, Outlet (Operating) & $71^{\circ} \mathrm{C}\left(160^{\circ} \mathrm{F}\right)$ outlet \\
\hline \multicolumn{2}{|c|}{$\begin{array}{l}\text { a. Maximum design power of } 250 \mathrm{MW} \text {. ATR typically operates at a total core power of less } \\
\text { than } 115 \mathrm{MW} \text {. }\end{array}$} \\
\hline
\end{tabular}

The ATR has five lobes which are loosely coupled. These five lobes are identified as Northwest (NW), Northeast (NE), Center (C), Southwest (SW), and Southeast (SE). During full power operation, operators can maintain the desired lobe power by rotating the Outer Shim Control Cylinders (OSCC) and withdrawing/inserting the neck shim control rods. Each lobe within the ATR can be viewed, quasiindependent reactor such that the ATR is virtually five smaller reactors. A Lobe-by-Lobe (LbyL) conversion strategy will be developed in order to minimize the impact to experiments within the other lobes. 


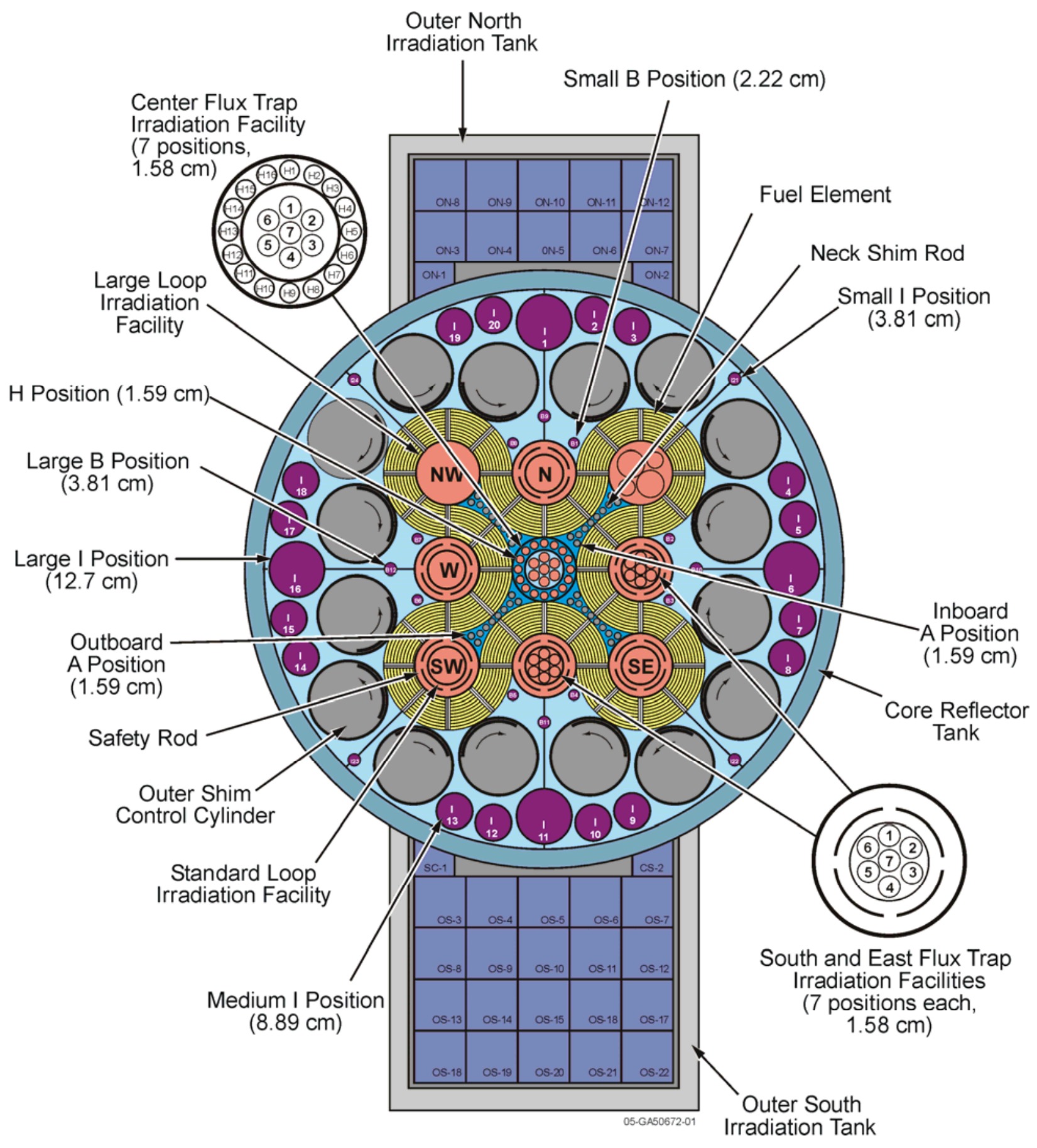

Figure 1. ATR Core Configuration Cross Sectional Diagram

(Nine flux traps and 68 Irradiation Test Positions). 


\section{Detailed Plate-by-Plate MCNP ATR Full Core Model}

The detailed plate-by-plate MCNP ATR model was used to generate Figure 2. The 40 fuel elements (FE) are explicitly modeled with 19 plates per FE.

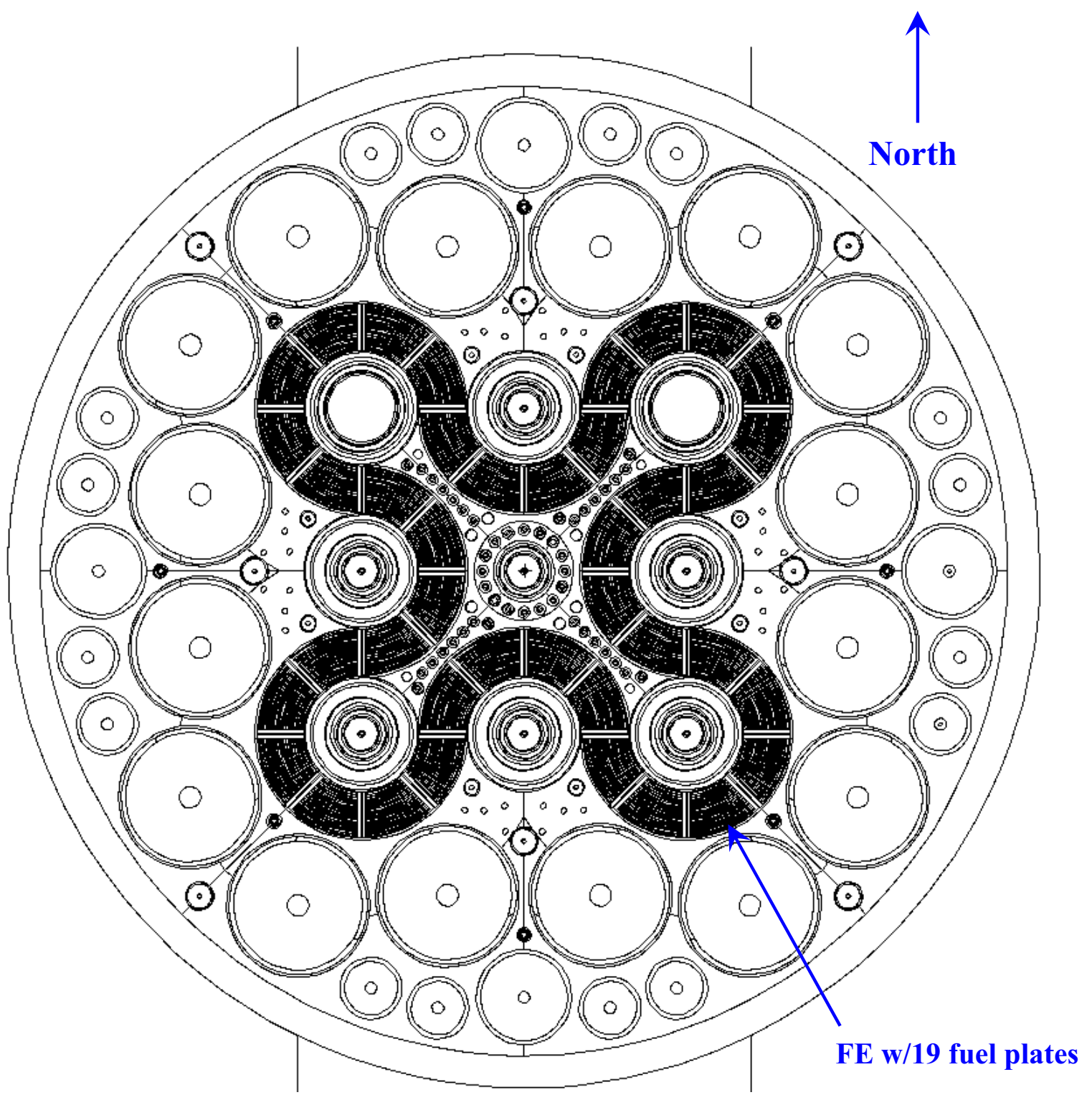

Figure 2. ATR MCNP full core model with 19 fuel plates per FE. 


\subsection{Validation of the Plate-by-Plate MCNP ATR Full Core Model}

The ability to accurately predict K-eff and fission power distribution within the 19 fuel plates using the MCNP model is essential to the ATR LEU core conversion design. The purpose of this section is to discuss the difference in K-eff calculated by MCNP (Case-1) and PDQ (Case-2) ${ }^{1}$ models with respect to the Cycle 134A (Case-3) ATR SUrveillance DAta System (ASUDAS) ${ }^{2}$ data. The ATR Cycle 134A core configuration was modeled using MCNP and PDQ, then input parameters were adjusted to reflect the asrun Cycle 134A initial critical conditions given in Table 2.

Table 2. ATR Cycle 134A ASUDAS (as-run) initial critical conditions.

\begin{tabular}{|l|c|}
\hline \multicolumn{1}{|c|}{ Parameter } & $\begin{array}{c}\text { Case-3 } \\
\text { ASUDAS Data }\end{array}$ \\
\hline Balanced OSCC Position & $39.2^{\circ}$ \\
K-eff & 1.00 (Critical) \\
Neck Shim Positions & \\
NW-1 thru NW-6 & All inserted \\
NE-1 thru NE-6 & All inserted \\
SW-1 thru SW-3, SW-5 thru SW-6 & All inserted \\
SE-1 thru SE-3, SE-5 thru SE-6 & All inserted \\
\hline
\end{tabular}

The PDQ calculations were performed using the PDQWS ${ }^{3}$ computer code. Because the PDQ core model uses a discrete X-Y mesh to divide the cells, the balanced outer shim position was modeled at $40.1^{\circ}$, which was the closest available position to the ASUDAS value of $39.2^{\circ}$. The MCNP and PDQWS calculated results and ASUDAS data are tabulated in Table 3.

Table 3. Initial critical conditions for ATR Cycle 134A (MCNP, PDQWS, and ASUDAS).

\begin{tabular}{|l|c|c|}
\hline \multicolumn{1}{|c|}{ Case } & $\begin{array}{c}\text { Balanced } \\
\text { OSCC Position }\end{array}$ & K-eff \\
\hline Case-1 (MCNP) & $39.2^{\circ}$ & 1.0011 \\
Case-2 (PDQWS) & $40.1^{\circ}$ & 0.9886 \\
Case-3 (ASUDAS) & $39.2^{\circ}$ & 1.0000 \\
\hline
\end{tabular}

Case-1 compared to Case- 3

$$
\Delta \mathrm{K} \text {-eff }(\mathrm{ASUDAS}-\mathrm{MCNP})=1.0000-1.0011=-0.0011
$$

\section{Case-2 compared to Case-3}

$$
\Delta \mathrm{K} \text {-eff }(\text { ASUDAS }- \text { PDQWS })=1.0000-0.9886=0.0114
$$

From these calculations, it was concluded that (a) the bias of PDQ ATR model with respect to ASUDAS data is 0.0114 , while (b) the bias of the ATR full core MCNP model with respect to ASUDAS 
data is -0.0011 , and (c) the ATR full core MCNP K-eff calculation and ASUDAS measured data are in good agreement.

\section{Plate-by-Plate ATR $1 / 8^{\text {th }}$ Core Model for Fuel Burnup Analysis}

A detailed plate-by-plate MCNP ATR $1 / 8^{\text {th }}$ core model (Figure 3) was derived from the validated MCNP ATR full core model for the fuel cycle burnup analysis. This model is used to optimize the U-235 loading in the LEU core by minimizing the K-eff differences with respect to the HEU core after 125 EFPDs of operation with a total core power of $115 \mathrm{MW}$ (23 MW per lobe). FE-18 details are shown in Figure 4.

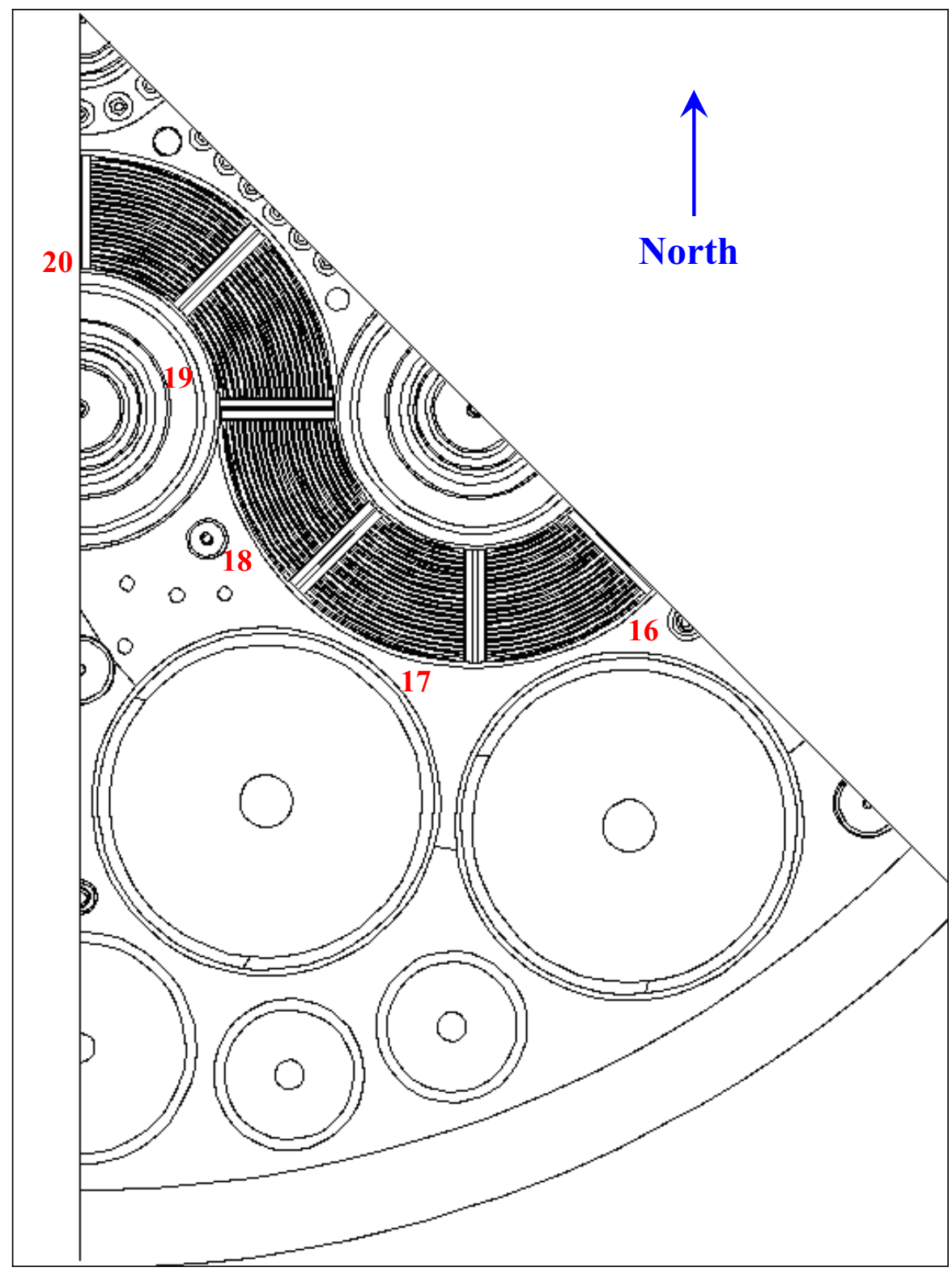

Figure 3. Detailed ATR SE-lobe $1 / 8^{\text {th }}$ core MCNP model (FEs $\left.16-20\right)$. 


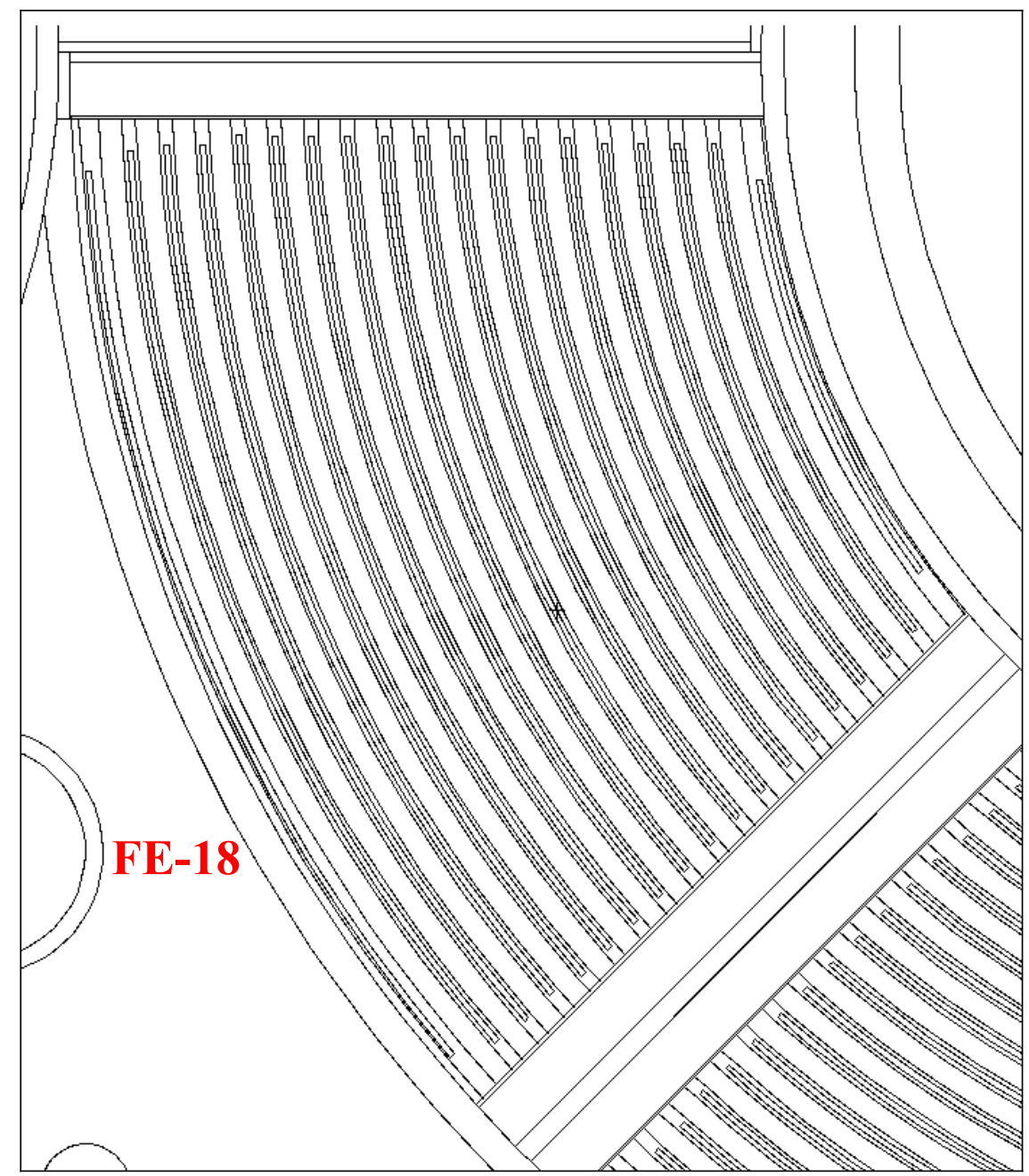

Figure 4. ATR MCNP model FE-18 detail.

\section{MCWO - Fuel Burnup Analysis Tool}

The fuel burnup analysis tool used in this study consists of a BASH script file that links together the two FORTRAN data processing programs, m2o.f ${ }^{4}$ and o2m.f. ${ }^{4}$ This burnup methodology couples the Monte Carlo transport code MCNP ${ }^{5,6}$ with the radioactive decay and burnup code ORIGEN2., ${ }^{7}$ The

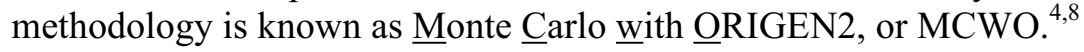

The MCWO methodology produces criticality and burnup data based on various material feed/removal specifications, core power(s), and irradiation time intervals. MCWO processes userspecified input for geometry, initial material compositions, feed/removal specifications, and other problem-specific parameters.

The MCWO methodology uses MCNP-calculated one-group microscopic cross sections and fluxes as input to a series of ORIGEN2 burnup calculations. ORIGEN2 depletes/activates materials and generates isotopic compositions for subsequent MCNP calculations.

MCWO performs one MCNP and one or more ORIGEN2 calculations for each user-specified time step. Due to the highly time-dependent nature of the physics parameters and material compositions of the 
modeled reactor system, the MCWO-calculated results are typically more accurate if long irradiation cycles are broken up into smaller intervals. It should be noted that an increase in the number of ORIGEN2 calculation steps does not significantly impact the overall MCWO execution time because MCNP dominates the MCWO execution time.

For each MCNP calculation step, MCNP updates the fission power distribution and burnupdependent cross sections for each fuel plate, then transfers the data to ORIGEN2 for cell-wise depletion calculations. The MCNP-generated reaction rates are integrated over the continuous-energy nuclear data and the space within the region.

\section{Initial Evaluation of HEU and three LEU Cases}

MCWO was used to perform an initial evaluation of the fuel cycle performance versus the EFPDs for the following cases:

$\begin{array}{ll}\text { Case-A } & \text { ATR reference HEU, } 20 \text { mil thick fuel meat, } \\ & \text { 1075 g U-235, 0.66 g B-10 for } 4 \text { inner/outer plates } \\ \text { Case-B } & \text { Foil type LEU, un-optimized, constant } 13 \text { mil thick U-10Mo fuel meat, } \\ & \text { 1565.77 g U-235 } \\ \text { Case-C } & \text { Foil type LEU, optimized by varying U-10Mo fuel meat thickness, } \\ & \text { 1400.11 g U-235 0.77 g B-10 for } 4 \text { inner/outer plates } \\ \text { Case-D } & \text { Foil type LEU, optimized by varying U-10Mo fuel meat thickness, } \\ & \text { 1393.93 g U-235 7.0 g Cd for } 4 \text { inner/outer plates }\end{array}$

The analysis assumed that each nominal operating cycle was 50 EFPDs followed immediately by a seven day outage. Each 50 EFPD cycle was subdivided into 5 EFPD time step intervals. The OSCC positions were set to $105^{\circ}$. The resultant MCNP-calculated tallies were normalized to a south lobe source power of $23 \mathrm{MW}$.

\subsection{Comparison of K-eff versus EFPDs for ATR Reference HEU (Case-A) and Un-optimized Foil Type LEU (Case-B)}

The MCWO-calculated results of the bias adjusted K-eff versus EFPDs for Case-A and Case-B demonstrates that the ATR HEU fuel provides adequate excess reactivity (for K-eff larger than one) for about 120 EFPDs of reactor power operation.

The MCWO-calculated results of the bias adjusted K-eff versus EFPDs for Case-B demonstrates that the foil type LEU fuel provides adequate excess reactivity (for K-eff larger than one) for about 120 EFPDs of reactor power operation. The fuel density for Case-B was $16.88 \mathrm{~g} / \mathrm{cc}$ with $1204.2 \mathrm{~g}$ of U-235.

The MCWO-calculated K-eff for HEU Case-A and LEU Case-B are plotted in Figure 5. Please note that at the beginning of cycle (BOC) for each of the three nominal operating cycles modeled, the initial Xe poison was set to zero or decayed to a very small value during the 7 day shutdown time, thus causing a jump increase in K-eff. 


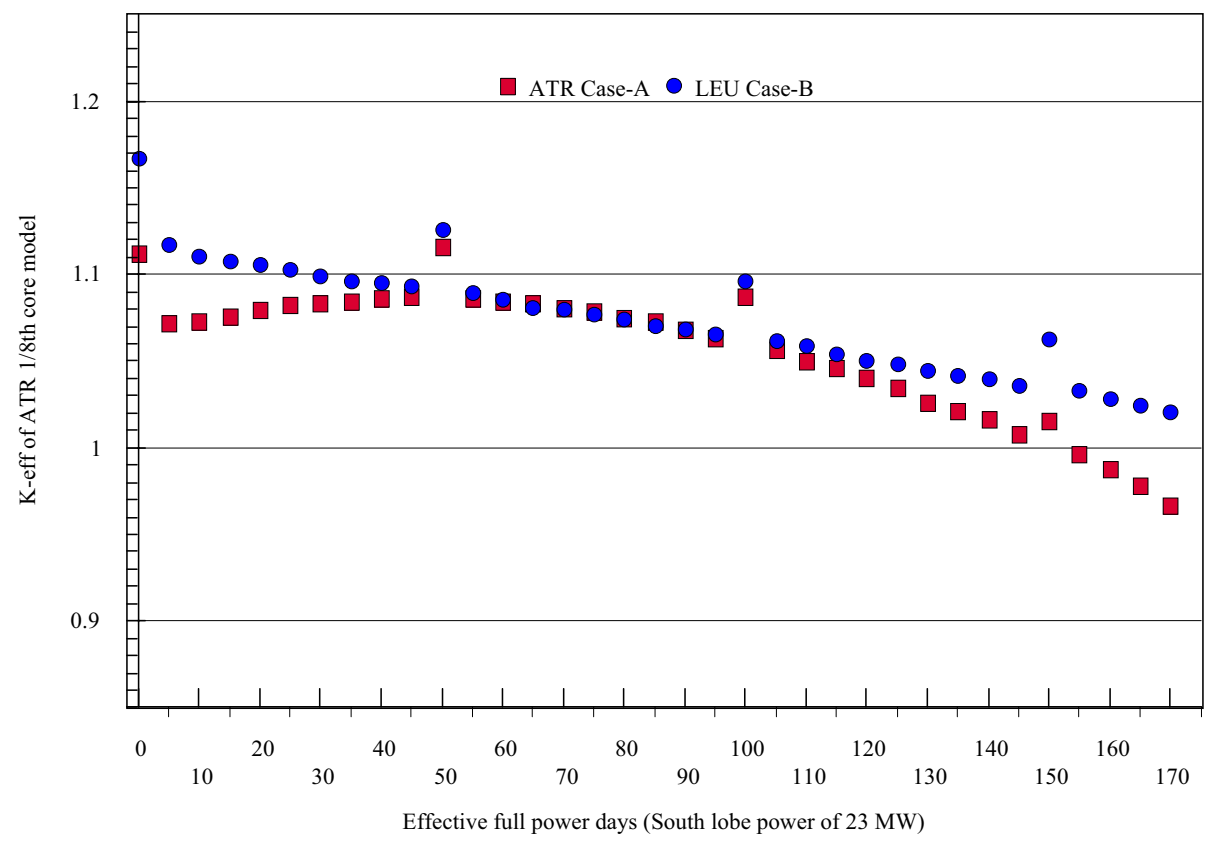

Figure 5. K-eff vs. EFPDs for ATR reference HEU Case-A and un-optimized LEU Case-B.

\subsection{Comparison of Radial Fission Power Profiles at BOC for ATR Reference HEU and Un-optimized LEU}

For the beginning of the first irradiation cycle, the relative radial fuel plate fission power heat fluxes were calculated for Case-A and Case-B and the results are plotted in Figure 6. The ATR reference HEU Case-A fuel plate specifications are given in Table 4. For the ATR reference HEU Case-A, the 4 inner/outer plates (plates 1-4 and 16-19) are loaded with $0.66 \mathrm{~g}$ of B-10, a burnable absorber, which flattens relative heat flux in the inner/outer plates to a peak value of about 1.22. Case-B does not have any burnable absorber in the 4 inner/outer fuel plates, therefore the peak relative heat flux ratio is approximately 1.63. When comparing the heat fluxes at the inner/outer plates for the ATR reference HEU Case-A and the un-optimized LEU Case-B, it was obvious that the LEU Case-B yields significantly higher heat fluxes at the inner and outer plates. Note that for FE-18, the respective peak heat fluxes localto-average-ratios (L2ARs) for Case-A and Case-B were determined to be 1.30 and 1.63, respectively.

Based upon the comparison between Case-A and Case-B heat fluxes, the U-235 contents and fuel meat thickness of the inner/outer plates were evaluated and optimized that in order to reduce the LEU heat flux L2AR,. The LEU fuel loading was optimized such that the L2AR at the 4 inner/outer plates was bounded by ATR reference HEU Case-A. The optimization was achieved by reducing the fuel meat thickness as well as loading the inner/outer plates with $0.8 \mathrm{~g}$ of B-10, LEU Case-C. The optimized LEU fuel plate specifications are given in Table 5 .

Because the B-10 $(n, \alpha)$ reaction will produce Helium-4 (He-4), which might degrade the LEU foil type fuel performance, an alternative absorber option is proposed. LEU Case-D will have $6.918 \mathrm{~g}$ of Cadmium $(\mathrm{Cd})$ mixed with the LEU fuel. The optimized LEU fuel meat thickness, burnable absorber loading, fuel meat volumes are tabulated in Table 6. 


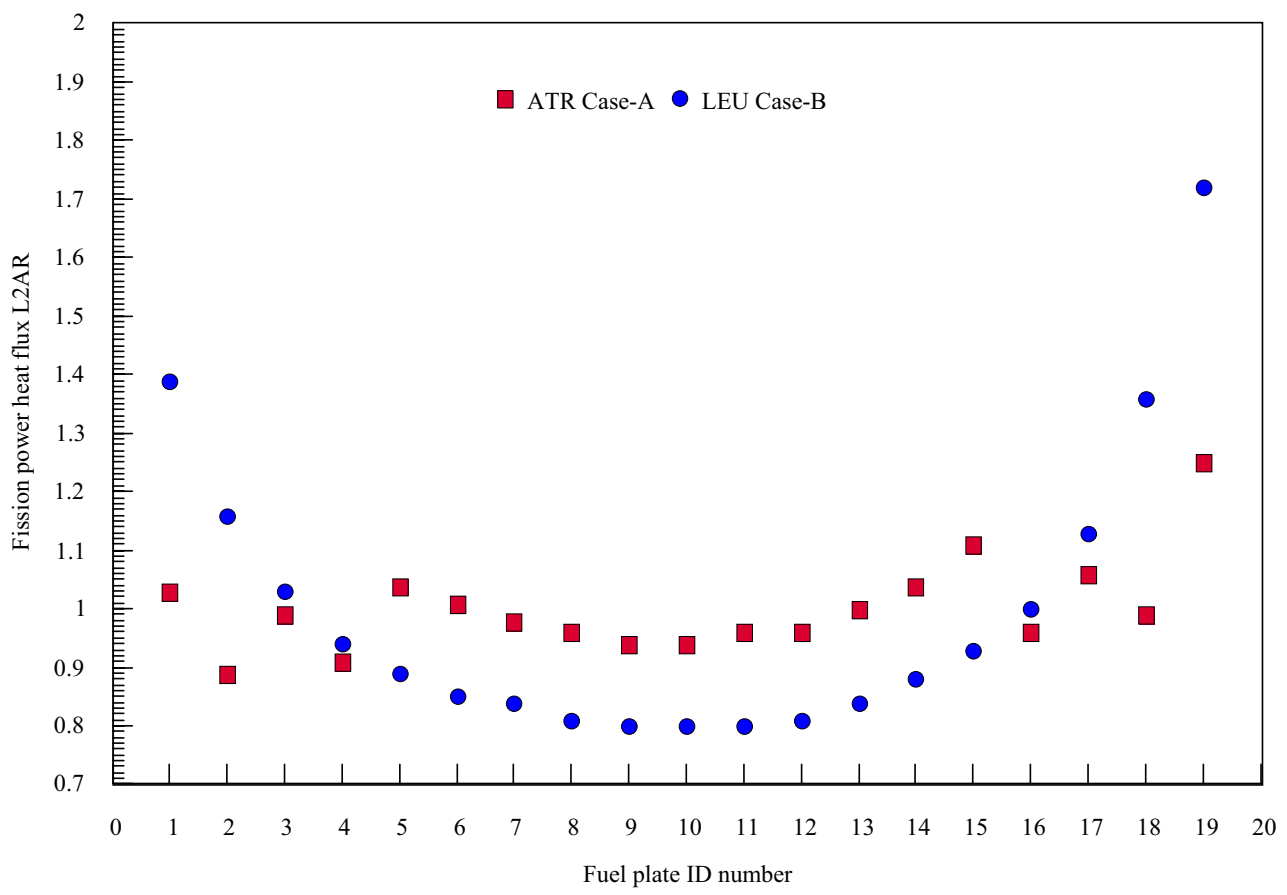

Figure 6. Radial fission power heat flux L2AR for ATR reference HEU Case-A, and un-optimized LEU Case-B. 
Table 4. Specifications for a ATR reference HEU (U-235 93wt $\%$ ) FE with B-10 in the 4 inner/outer fuel plates.

\begin{tabular}{|c|cc|c|c|c|}
\hline HEU & $\begin{array}{c}\text { Fuel Meat } \\
\text { Thickness } \\
\text { Plate }\end{array}$ & $\begin{array}{c}\text { Fuel Meat } \\
\text { Volume } \\
\text { (mc) }\end{array}$ & $\begin{array}{c}\text { U-235 } \\
\text { Mass } \\
\text { (g) }\end{array}$ & $\begin{array}{c}\text { B-10 } \\
\text { Mass } \\
\text { (g) }\end{array}$ & $\begin{array}{c}\text { U-235 } \\
\text { Density } \\
\text { (g/cc) }\end{array}$ \\
\hline Plate-1 & 20 & 23.69 & 24.3 & 0.063 & 1.026 \\
Plate-2 & 20 & 29.54 & 29.1 & 0.078 & 0.985 \\
Plate-3 & 20 & 31.12 & 38.7 & 0.044 & 1.243 \\
Plate-4 & 20 & 32.7 & 40.4 & 0.045 & 1.235 \\
Plate-5 & 20 & 34.29 & 52.1 & -- & 1.52 \\
Plate-6 & 20 & 35.87 & 54.6 & -- & 1.522 \\
Plate-7 & 20 & 37.45 & 57 & -- & 1.522 \\
Plate-8 & 20 & 39.03 & 59.4 & -- & 1.522 \\
Plate-9 & 20 & 40.61 & 61.8 & -- & 1.522 \\
Plate-10 & 20 & 42.19 & 64.2 & -- & 1.522 \\
Plate-11 & 20 & 43.78 & 66.6 & -- & 1.521 \\
Plate-12 & 20 & 45.36 & 69 & -- & 1.521 \\
Plate-13 & 20 & 46.94 & 71.4 & -- & 1.521 \\
Plate-14 & 20 & 48.52 & 73.8 & -- & 1.521 \\
Plate-15 & 20 & 50.1 & 76.3 & -- & 1.523 \\
Plate-16 & 20 & 51.69 & 64 & 0.071 & 1.238 \\
Plate-17 & 20 & 53.27 & 65.9 & 0.073 & 1.237 \\
Plate-18 & 20 & 54.22 & 53.8 & 0.143 & 0.992 \\
Plate-19 & 20 & 52.64 & 52.6 & 0.143 & 0.999 \\
\hline Total & & 792.99 & 1075 & 0.66 & - \\
\hline
\end{tabular}


Table 5. Specifications for the optimized LEU (U-235 19.7wt\%) FE with B-10 in the 4 inner/outer fuel plates.

\begin{tabular}{|c|cc|c|c|c|}
\hline $\begin{array}{c}\text { LEU } \\
\text { Plate }\end{array}$ & $\begin{array}{c}\text { Fuel Meat } \\
\text { Thickness } \\
\text { (mil) }\end{array}$ & $\begin{array}{c}\text { Fuel Meat } \\
\text { Volume } \\
\text { (cc) }\end{array}$ & $\begin{array}{c}\text { U-235 } \\
\text { Mass } \\
\text { (g) }\end{array}$ & $\begin{array}{c}\text { B-10 } \\
\text { Mass } \\
\text { (g) }\end{array}$ & $\begin{array}{c}\text { U-235 } \\
\text { Density } \\
\text { (g/cc) }\end{array}$ \\
\hline Plate-1 & 7.80 & 9.186 & 27.73 & 0.063 & 3.02 \\
Plate-2 & 10.40 & 15.298 & 46.17 & 0.178 & 3.02 \\
Plate-3 & 11.70 & 18.196 & 54.92 & 0.044 & 3.02 \\
Plate-4 & 11.70 & 19.111 & 57.68 & 0.005 & 3.02 \\
Plate-5 & 13.00 & 22.181 & 66.95 & -- & 3.02 \\
Plate-6 & 13.00 & 23.658 & 71.41 & -- & 3.02 \\
Plate-7 & 13.00 & 24.709 & 74.58 & -- & 3.02 \\
Plate-8 & 13.00 & 25.745 & 77.71 & -- & 3.02 \\
Plate-9 & 13.00 & 26.796 & 80.88 & -- & 3.02 \\
Plate-10 & 13.00 & 27.823 & 83.98 & -- & 3.02 \\
Plate-11 & 13.00 & 28.889 & 87.19 & -- & 3.02 \\
Plate-12 & 13.00 & 29.922 & 90.31 & -- & 3.02 \\
Plate-13 & 13.00 & 30.972 & 93.48 & -- & 3.02 \\
Plate-14 & 13.00 & 32.008 & 96.61 & -- & 3.02 \\
Plate-15 & 13.00 & 33.065 & 99.80 & -- & 3.02 \\
Plate-16 & 11.70 & 30.202 & 91.16 & 0.001 & 3.02 \\
Plate-17 & 10.40 & 27.575 & 83.23 & 0.033 & 3.02 \\
Plate-18 & 7.80 & 21.060 & 63.56 & 0.133 & 3.02 \\
Plate-19 & 6.50 & 17.485 & 52.77 & 0.343 & 3.02 \\
\hline Total & & 463.88 & 1400.1 & 0.800 & -- \\
\hline
\end{tabular}


Table 6. Specifications for the optimized LEU (U-235 19.7wt\%) FE with $\mathrm{Cd}$ in the 4 inner/outer fuel plates.

\begin{tabular}{|c|cc|c|c|c|}
\hline $\begin{array}{c}\text { LEU } \\
\text { Plate }\end{array}$ & $\begin{array}{c}\text { Fuel Meat } \\
\text { Thickness } \\
\text { (mil) }\end{array}$ & $\begin{array}{c}\text { Fuel Meat } \\
\text { Volume } \\
\text { (cc) }\end{array}$ & $\begin{array}{c}\text { U-235 } \\
\text { Mass } \\
\text { (g) }\end{array}$ & $\begin{array}{c}\text { Cd } \\
\text { Mass } \\
\text { (g) }\end{array}$ & $\begin{array}{c}\text { U-235 } \\
\text { Density } \\
\text { (g/cc) }\end{array}$ \\
\hline Plate-1 & 7.80 & 9.186 & 27.60 & 0.545 & 3.00 \\
Plate-2 & 10.40 & 15.298 & 45.97 & 1.539 & 3.00 \\
Plate-3 & 11.70 & 18.196 & 54.68 & 0.380 & 3.00 \\
Plate-4 & 11.70 & 19.111 & 57.43 & 0.043 & 3.00 \\
Plate-5 & 13.00 & 22.181 & 66.65 & -- & 3.00 \\
Plate-6 & 13.00 & 23.658 & 71.09 & -- & 3.00 \\
Plate-7 & 13.00 & 24.709 & 74.25 & -- & 3.00 \\
Plate-8 & 13.00 & 25.745 & 77.36 & -- & 3.00 \\
Plate-9 & 13.00 & 26.796 & 80.52 & -- & 3.00 \\
Plate-10 & 13.00 & 27.823 & 83.61 & -- & 3.00 \\
Plate-11 & 13.00 & 28.889 & 86.81 & -- & 3.00 \\
Plate-12 & 13.00 & 29.922 & 89.91 & -- & 3.00 \\
Plate-13 & 13.00 & 30.972 & 93.07 & -- & 3.00 \\
Plate-14 & 13.00 & 32.008 & 96.18 & -- & 3.00 \\
Plate-15 & 13.00 & 33.065 & 99.36 & -- & 3.00 \\
Plate-16 & 11.70 & 30.202 & 90.76 & 0.009 & 3.00 \\
Plate-17 & 10.40 & 27.575 & 82.86 & 0.285 & 3.00 \\
Plate-18 & 7.80 & 21.060 & 63.28 & 1.150 & 3.00 \\
Plate-19 & 6.50 & 17.485 & 52.54 & 2.966 & 3.00 \\
\hline Total & & 463.88 & 1393.93 & 6.918 & -- \\
\hline
\end{tabular}

\subsection{Azimuthal Power Profiles}

To investigate the azimuthal fission power L2AR profiles, plates 2-19 were subdivided into 10 azimuthal regions and plate 1 was subdivided into 8 azimuthal regions. To investigate the axial fission power L2AR profiles, the 48 inch fuel plate length was axially subdivided into 32 equal length regions.

The MCNP-calculated results indicate that all HEU and LEU cases have similar azimuthal and axial fission power profiles, see Figure 7 and Figure 8, respectively. Therefore the average azimuthal and axial fission power profiles can and will be used for the fuel cycle burnup and thermal performance analysis. 


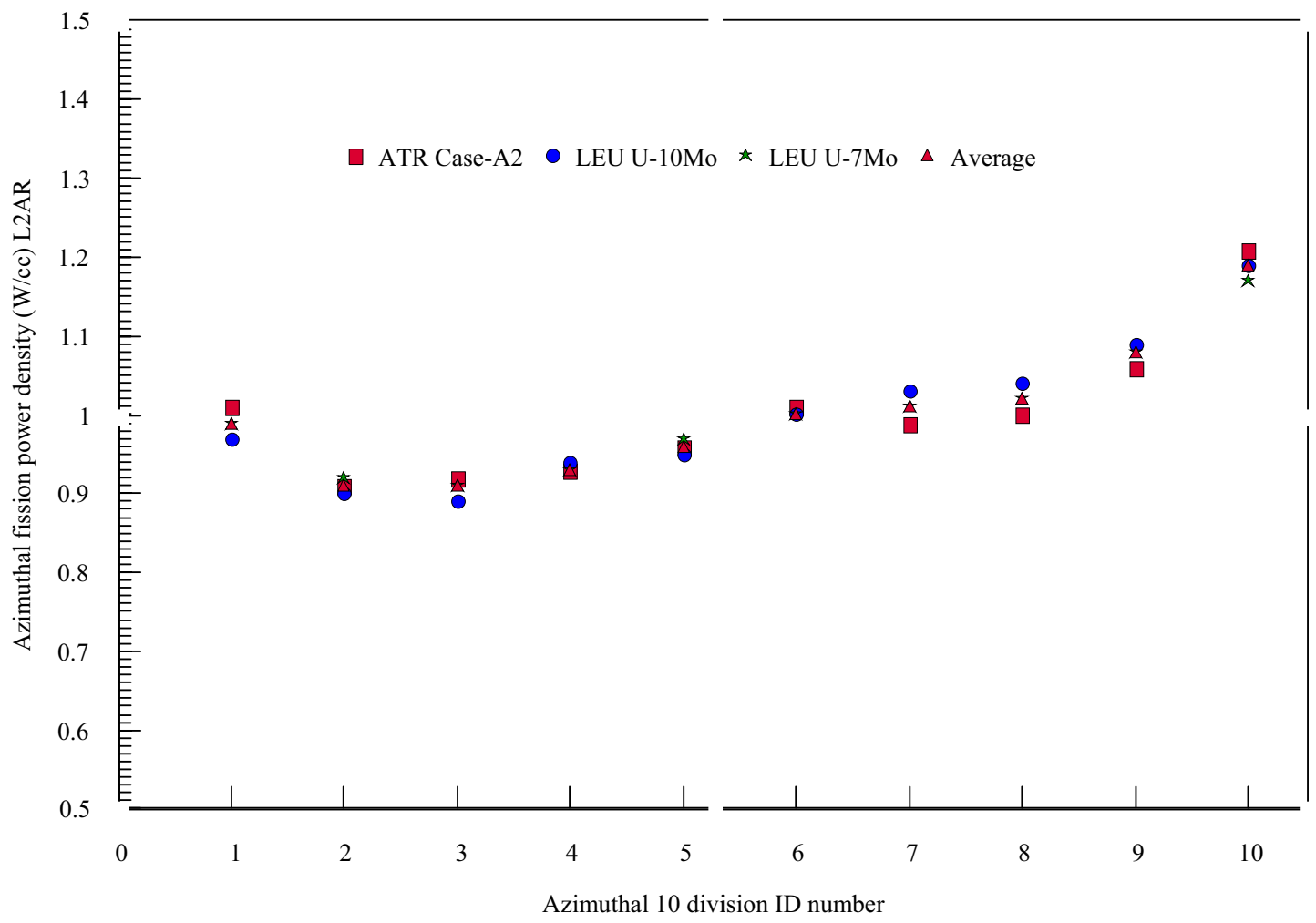

Figure 7. FE-18 Azimuthal distribution of fission power density L2AR.

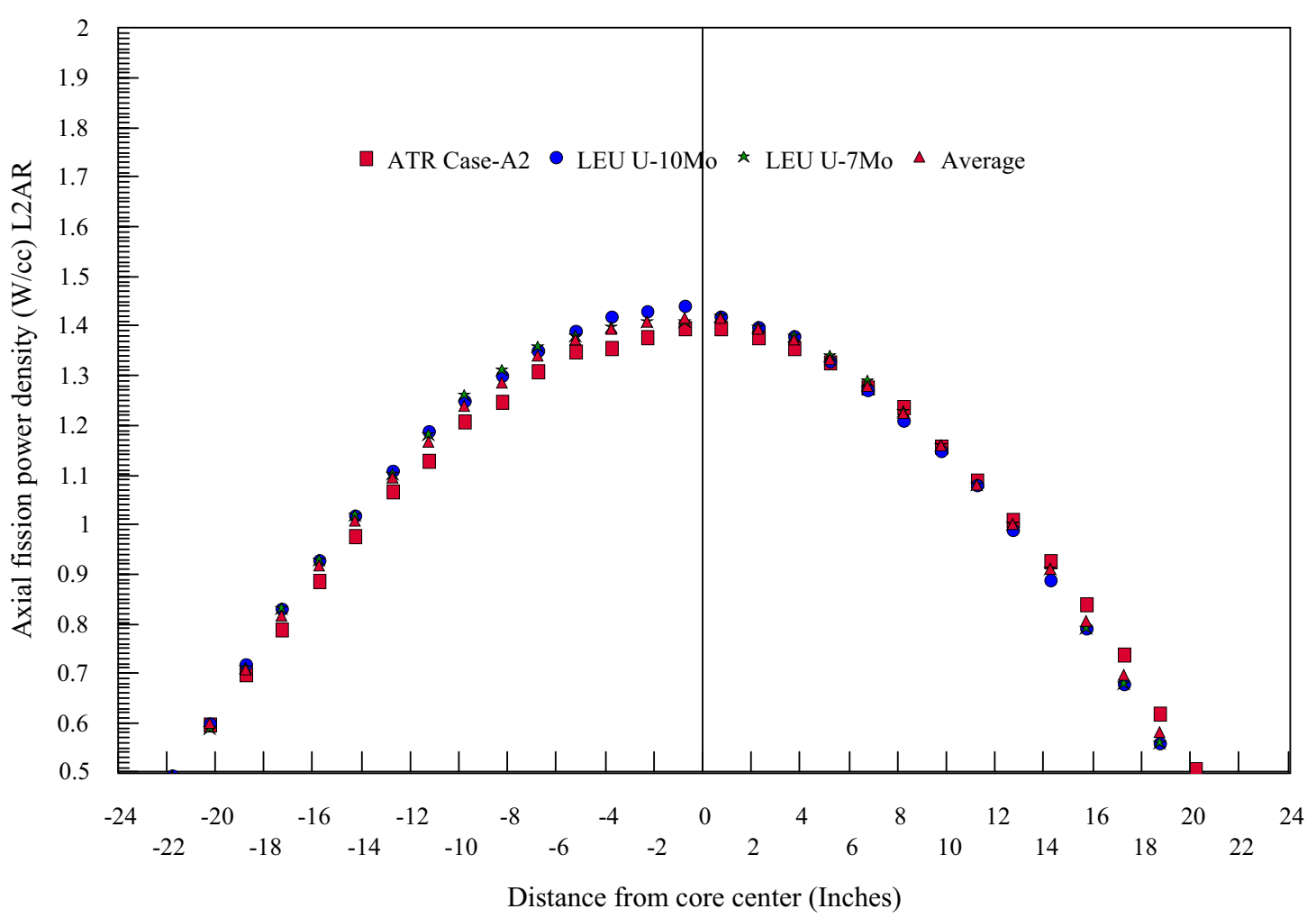

Figure 8. FE-18 Axial Distribution of fission power density L2AR. 


\section{Evaluation of HEU and Optimized LEU Fuel Cycle Performance}

Based on the results of previously discussed comparisons, a study was performed to optimize the radial power profile of the LEU fuel plates such that the profile closely matches that of the HEU reference Case-A. The optimization was based upon a comparison of the calculated radial power profile for various LEU fuel loading schemes. The LEU fuel (U-235 enrichment $19.7 \mathrm{wt} \%$ ) loading schemes included varying parameters such as fuel meat thickness within the U10-Mo LEU fuel types.

The case descriptions for the evaluated fuel loading studies are given below.

\section{HEU Standard ATR FE}

Case-A ATR standard HEU fuel assembly radial power profile with $0.66 \mathrm{~g}$ of B-10 in inner and outer 4 plates

LEU U-10Mo

Case-B Un-optimized foil type LEU, constant 13 mil thick U-10Mo fuel meat, $1565.77 \mathrm{~g}$ $\mathrm{U}-235$.

Case-C LEU U-10Mo fuel assembly radial power profile with $0.77 \mathrm{~g}$ of B-10 in inner and outer 4 plates (Optimized with fixed U-235 $19.7 \mathrm{wt} \%$ and varying fuel meat thickness.)

Case-D LEU U-10Mo Fuel assembly radial power profile with 7.0g of Cadmium in inner and outer 4 plates (Optimized with fixed U-235 $19.7 \mathrm{wt} \%$ and varying fuel meat thickness.)

\subsection{Optimized LEU Radial Fission Power Profile at BOC}

Table 5 and Table 6 summarize the parameter variations that resulted in the flattest radial fission heat profile while still maintaining sufficient reactivity within the LEU core. Not surprisingly, the optimal LEU fuel loading is similar to the HEU reference case. The optimal LEU fuel loading has thinner plates at the inner/outer plate positions. For the purposes of determining the feasibility of HEU to LEU conversion, however, the present study demonstrates a satisfactory loading scheme to achieve acceptable reactivity for three nominal 50 EFPD fuel cycles as well as maintain the radial heat flux L2AR profile.

The MCWO methodology was used to calculate the relative radial plate fission power heat flux for the optimized LEU cases for the beginning of the first cycle. In FE-18, the respective peak heat fluxes L2AR for Case-A, Casae-C, and Case-D were determined to be 1.22, 1.13, and 1.14, respectively. Results for Case-A, Case-C, and Case-D are plotted in Figure 9. This plot demonstrates that Case-C and Case-D yield very similar radial L2AR profiles as compared to Case-A. 


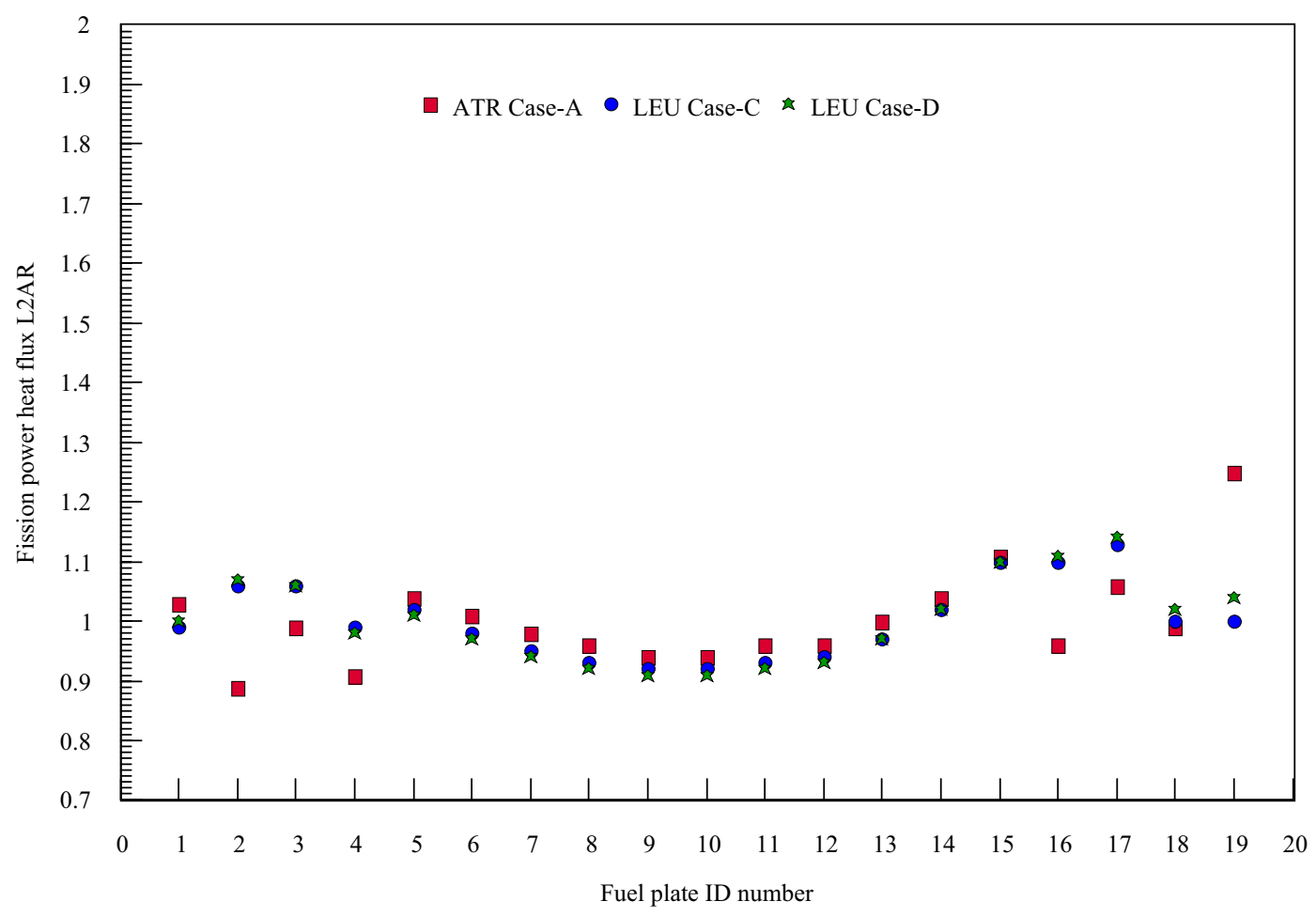

Figure 9. Fission power heat flux L2AR radial profiles for HEU Case-A and optimized LEU Case-C and Case-D.

\subsection{Optimized LEU K-eff versus EFPDs}

Using the optimized LEU fuel loading, the MCWO-calculated K-eff for LEU Case-C and Case-D as a function of EFPDs as compared to the ATR reference HEU Case-A is shown in Figure 10. Please note that the LEU fuels contain $80.3 \mathrm{wt} \% \mathrm{U}-238$, which can be transmuted to Pu-239. Although the LEU cases have a lower K-eff at the BOC when compared with HEU Case-A, the LEU cases sustain operation for more EFPDs than HEU Case-A (at least 130 EFPDs). 


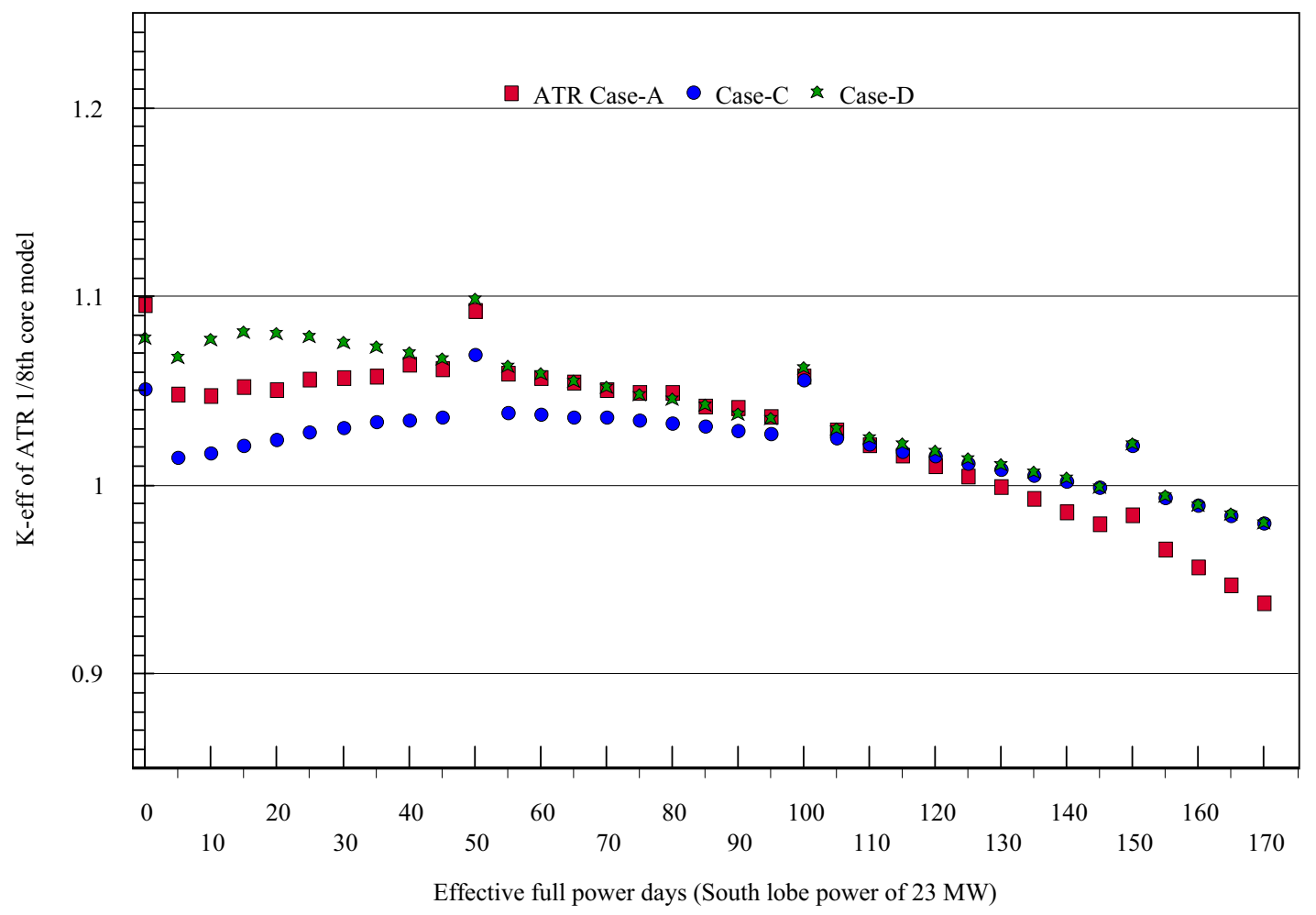

Figure 10. MCWO-calculated K-eff versus EFPDs for ATR reference HEU Case-A and optimized LEU Case-C and Case-D

These studies indicate that the LEU radial L2AR profiles can achieve flattened profiles bounded by HEU reference Case-A by varying fuel meat thickness of the inner/outer 4 plates. Although, the fission power density $\left(\mathrm{W} / \mathrm{cm}^{3}\right)$ L2AR profiles for the LEU cases with varied fuel meat thickness produced larger peaks within the inner/outer plates. This power density peaking will not result in large, undesirable heat flux profile.

\section{HEU and LEU Core Thermal-Hydraulic Evaluation}

The thermal-hydraulic characteristics of a reactor core that need to be evaluated are the departure from nucleate boiling (DNB) and flow instability (FI). Additionally, the fuel meat temperature and hence cladding temperature need to be evaluated to address the possible formation of blisters on the fuel plate due to the fission gas buildup in the fuel meat. For purposes of this preliminary evaluation, it is assumed that the fuel plate blister behavior between the HEU and LEU fuels is equivalent. It is also assumed that the current HEU core and LEU core will have identical physical dimensions for fuel plate thickness and coolant channel. These assumptions will result in equivalent flow velocities and equivalent hydraulic characteristics.

Typically, two accident scenarios are considered when performing safety analysis for the ATR. These accidents result in either a power/coolant mismatch or a power excursion due to a rapid reactivity insertion. The power coolant mismatch events are slow compared to the reactivity events and generally challenge safety margins associated with DNB or FI. The reactivity insertions are rapid and most of the 
energy will result in fuel temperature increase. The ATR evaluation criteria are fuel centerline temperature and margins to aluminum-water ignition. The difference in the two accident types result in a potential for two evaluation criteria for a fuel. The DNBR and FI are primarily dependent on a heat flux, while the consequences of a reactivity transient are primarily dependent on the volumetric heat rate in the fuel, the density and heat capacity of the fuel matrix, and the thermal conductivity of the fuel matrix.

Thus far, the neutronic studies indicate that the heat flux can be matched for the two fuel types by varying the fuel meat thickness with a constant U-235 enrichment. However, varying fuel meat thickness results in fuel meat power densities for some of the fuel plates for the LEU core being higher than those for the HEU core. Preliminary thermal evaluations were performed for the HEU and LEU optimization using an ABAQUS model that represents the physical dimensions of the ATR fuel element. The model utilized the heat rates as contained in the Appendix, Tables A-1, and A-2. The axial profile was represented by the chopped cosine and the azimuthal factors were as reported in Appendix Table A-4 Results for the power excursion resulting from the Safety Analysis Report Condition 4 reactivity excursion are shown in Figures 11-20. The figures represent the temperature at the fuel-clad interface. Figure 21 and Figure 22 illustrate the bulk coolant rise in the coolant channel with the peak heat load. The preliminary analysis results indicate satisfactory thermal/hydraulic safety criteria can be met with the LEU core.

Further evaluations will be necessary to ascertain if the current ATR operational envelope can be maintained. The ATR operating limits are based on a point power concept and the safety margins are predicted using a Monte Carlo sampling technique that samples variables from 44 statistical parameters, many of which are derived from the physical characteristics of the fuel material, the variability of fabrication parameters, as well as reactor characteristics. Many will require redefinition as the conversion proceeds and fuel is actually fabricated in the ATR geometry. Nuclear characteristics, such as void coefficient of reactivity, Doppler feedback, and thermal characteristics such as specific heat, thermal conductivity will need to be used to establish final differences. These differences will then be identified, to support a preliminary assessment for demonstrating that the ATR UFSAR provides a safe operating envelop for LEU fuel. 


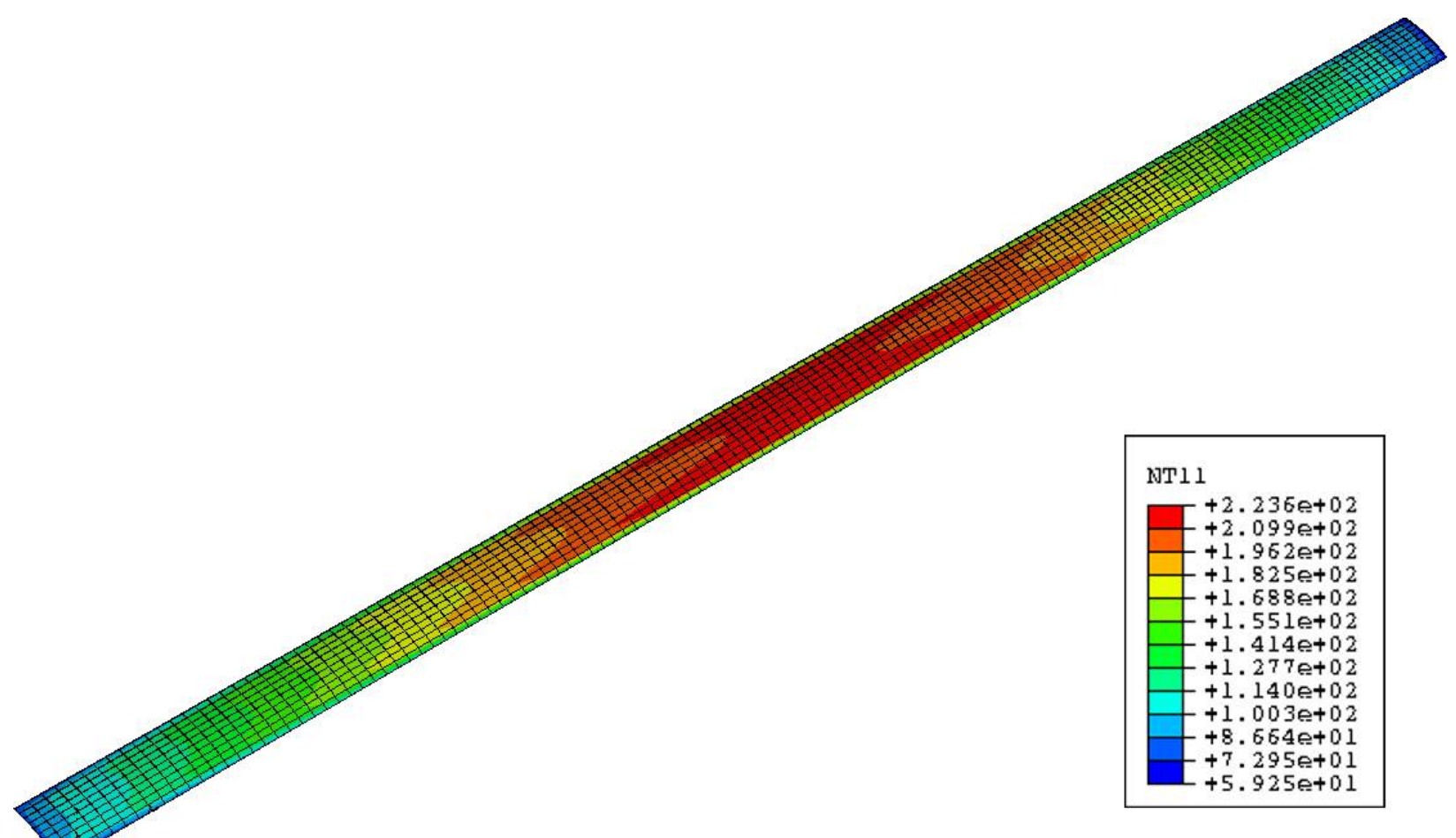

Figure 11. Temperature in LEU Plate 3 for Condition 4 Reactivity Insertion

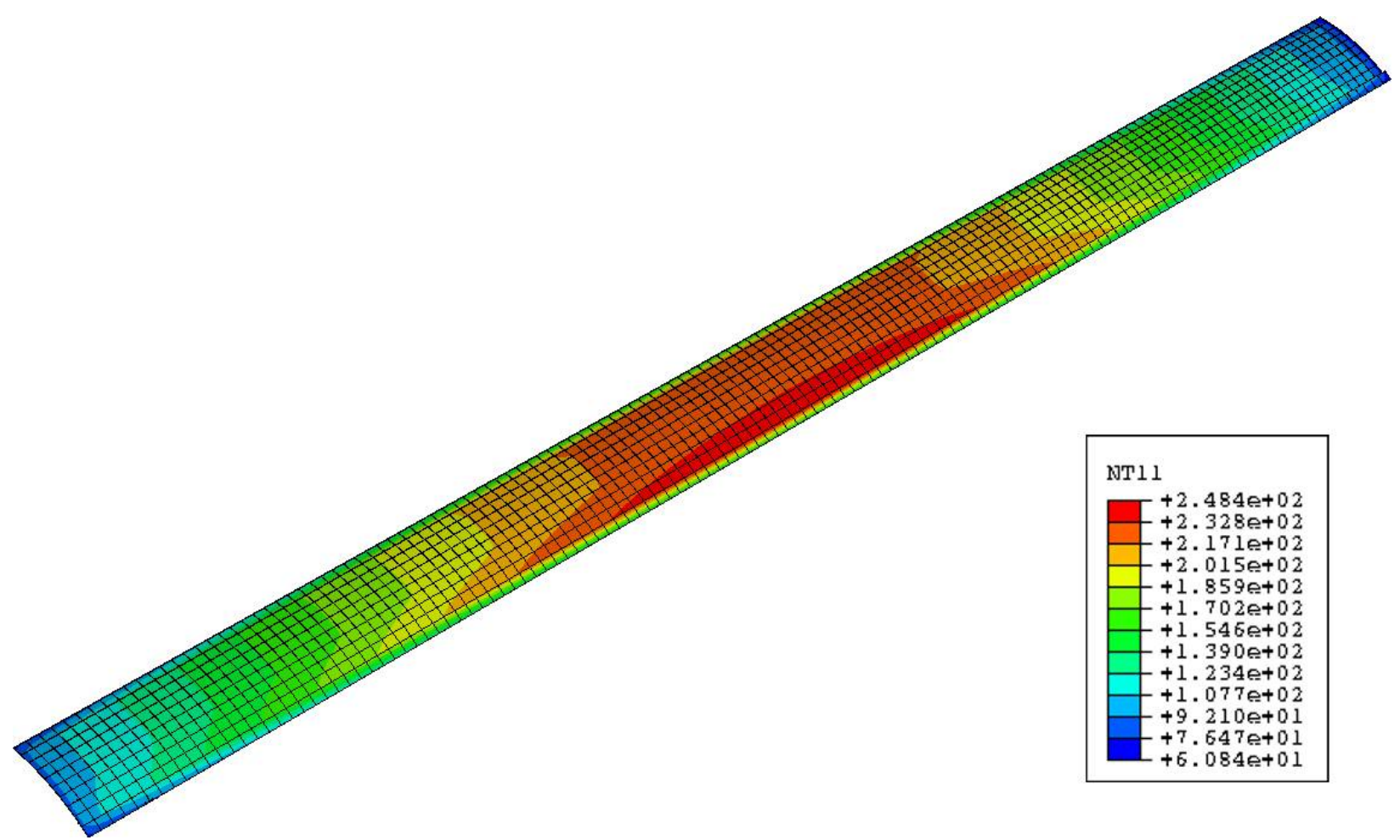

Figure 12. Temperature in LEU Plate 15 for Condition 4 Reactivity Insertion 


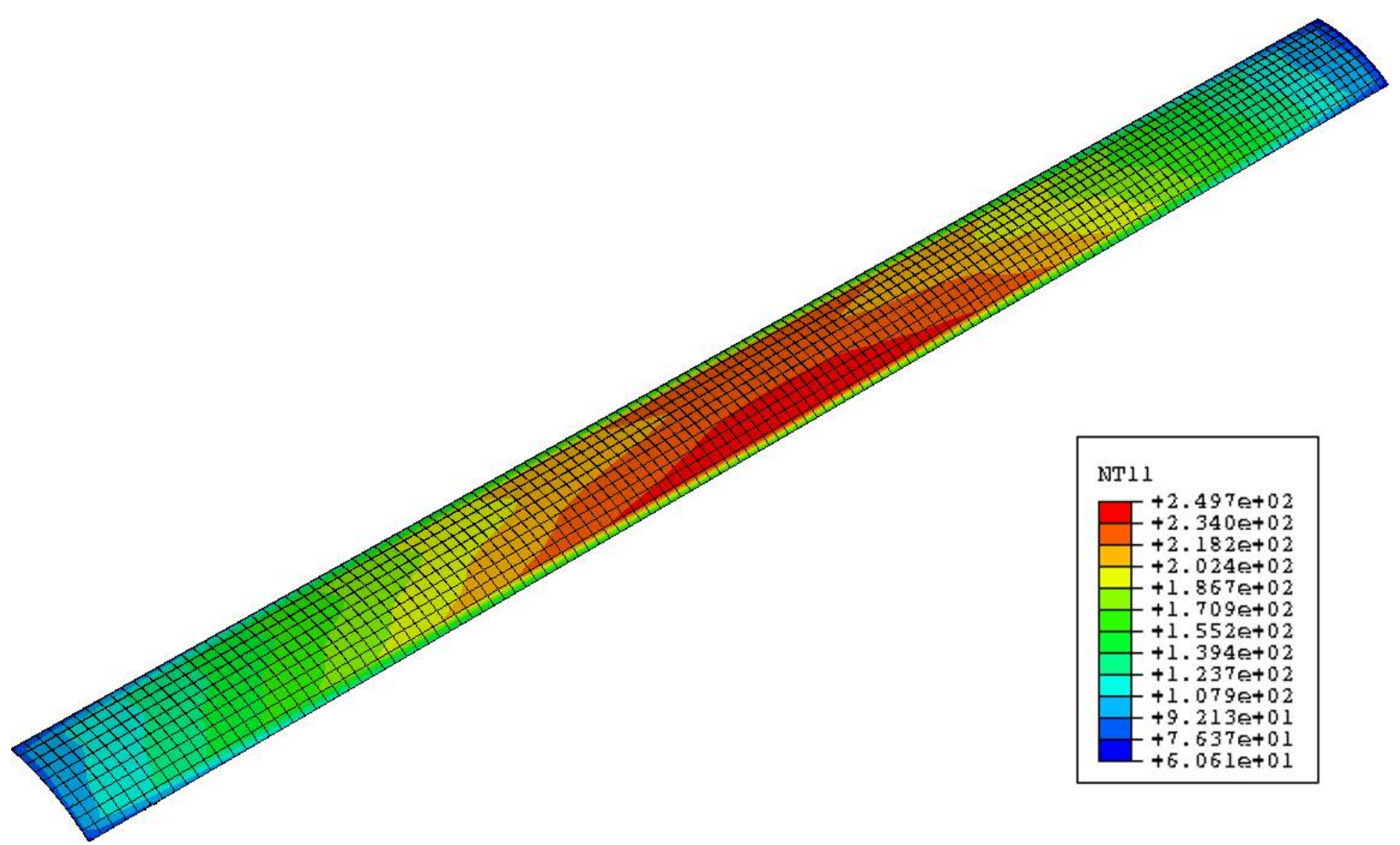

Figure 13. Temperature in LEU Plate 16 for Condition 4 Reactivity Insertion

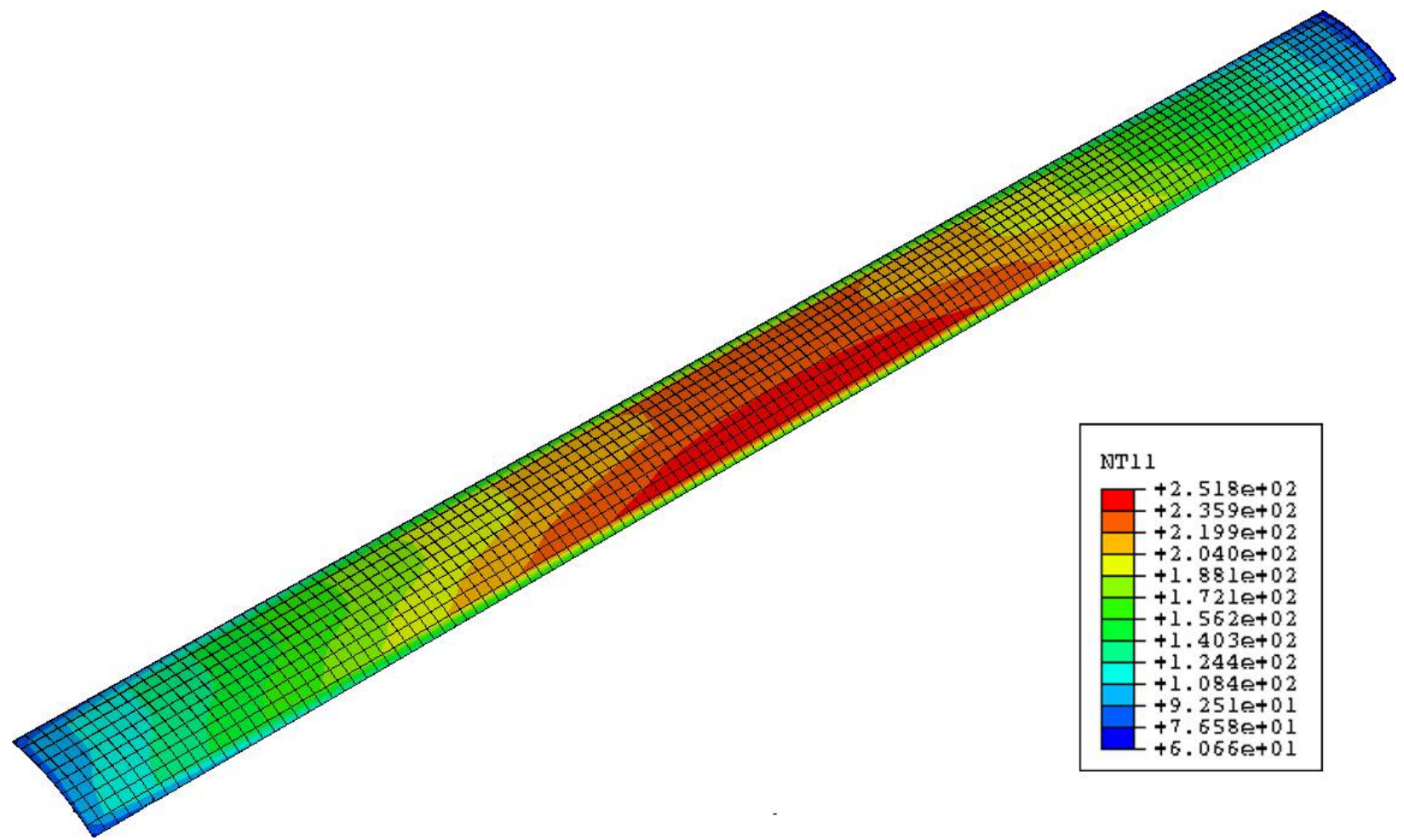

Figure 14. Temperature in LEU Plate 17 for Condition 4 Reactivity Insertion 


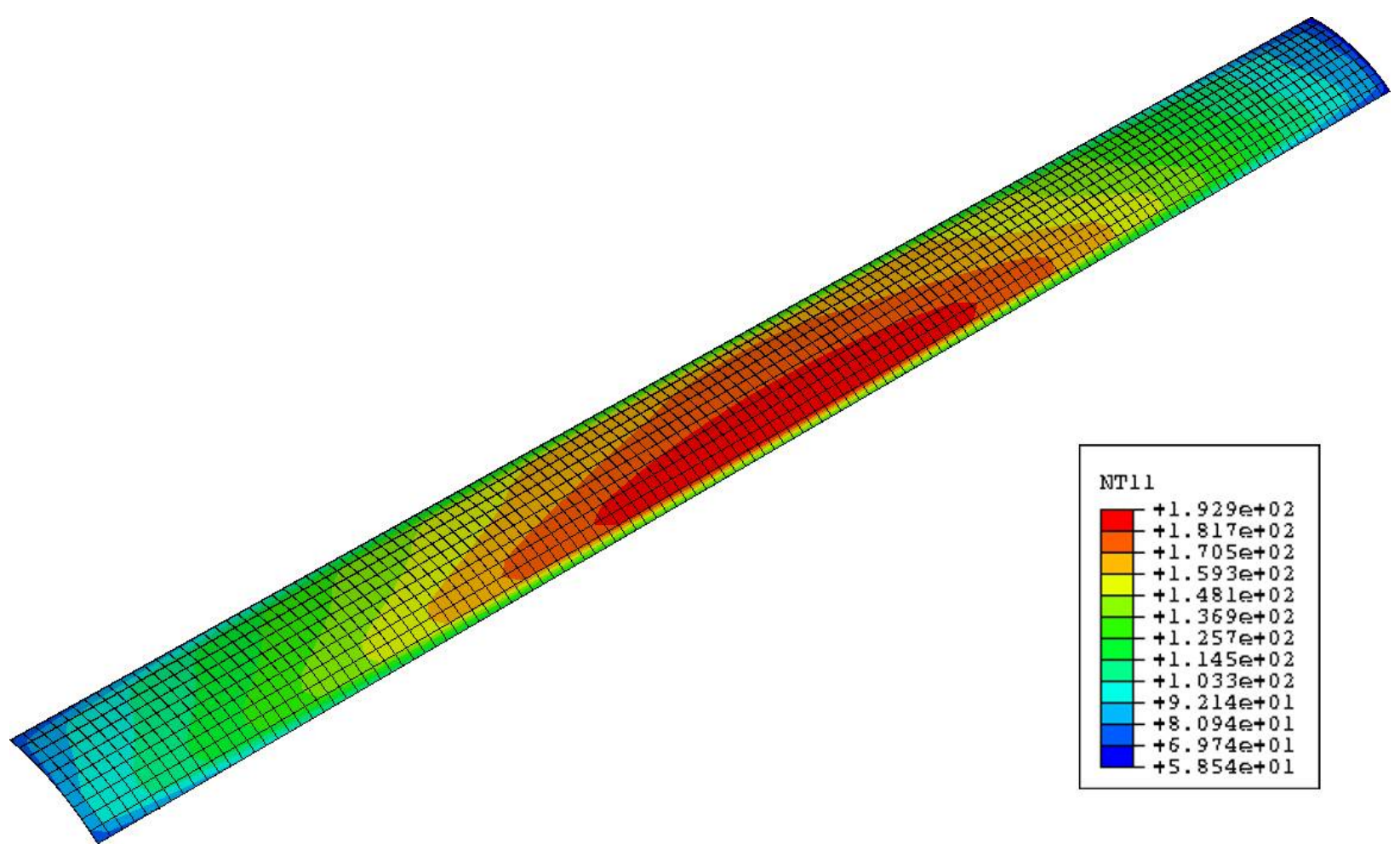

Figure 15. Temperature in LEU Plate 19 for Condition 4 Reactivity Insertion

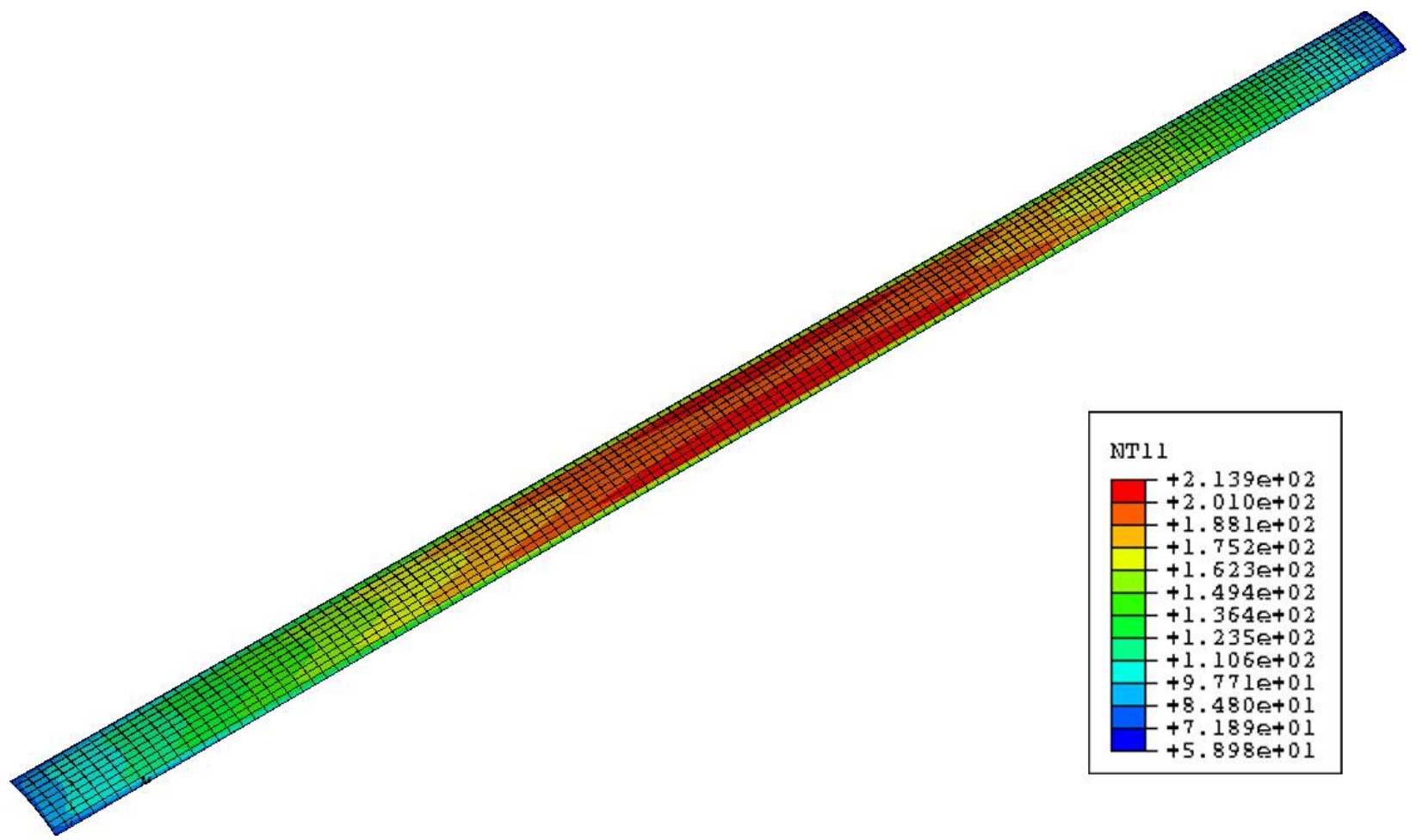

Figure 16.. Temperature in HEU Plate 3 for Condition 4 Reactivity Insertion 


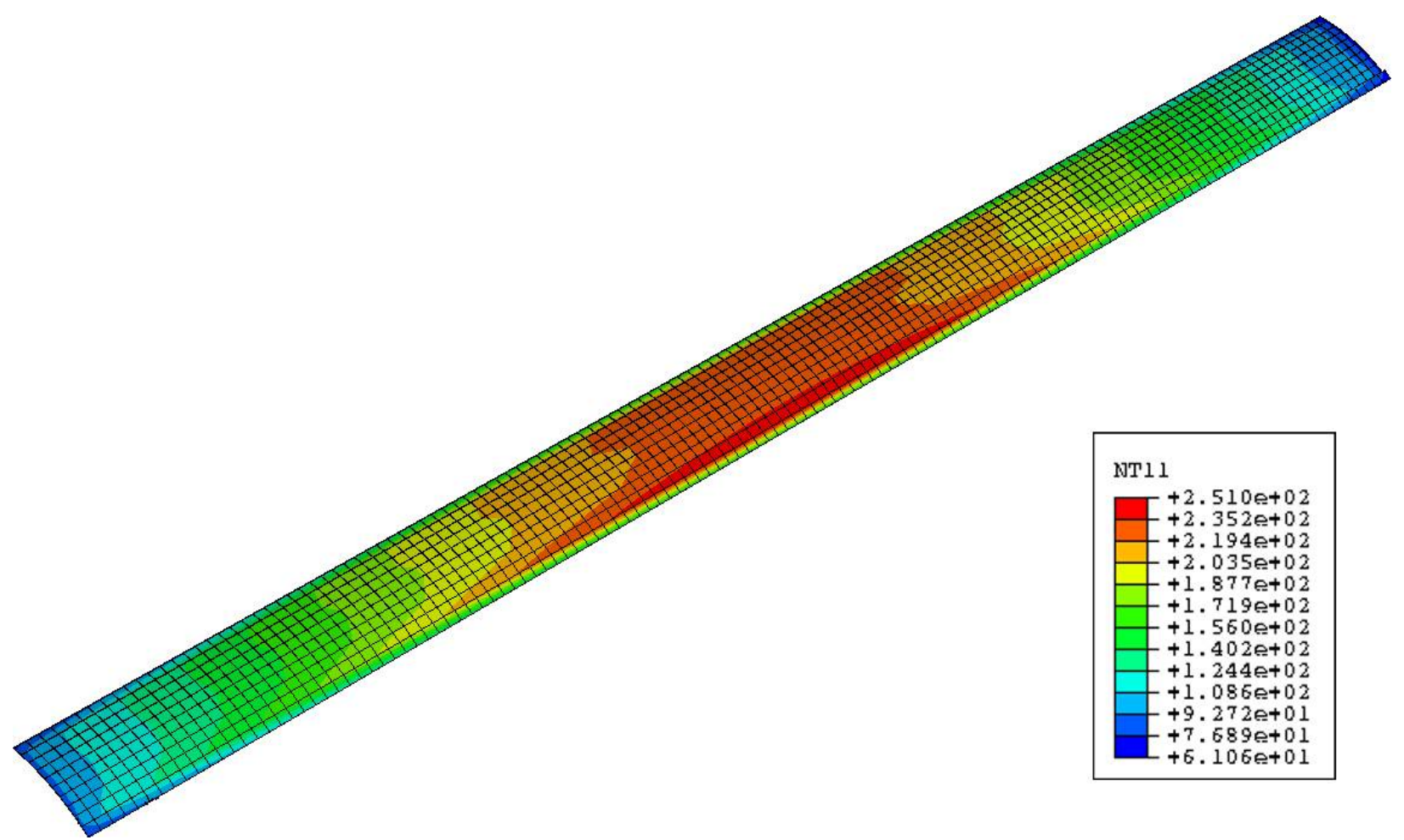

Figure 17. Temperature in HEU Plate 15 for Condition 4 Reactivity Insertion

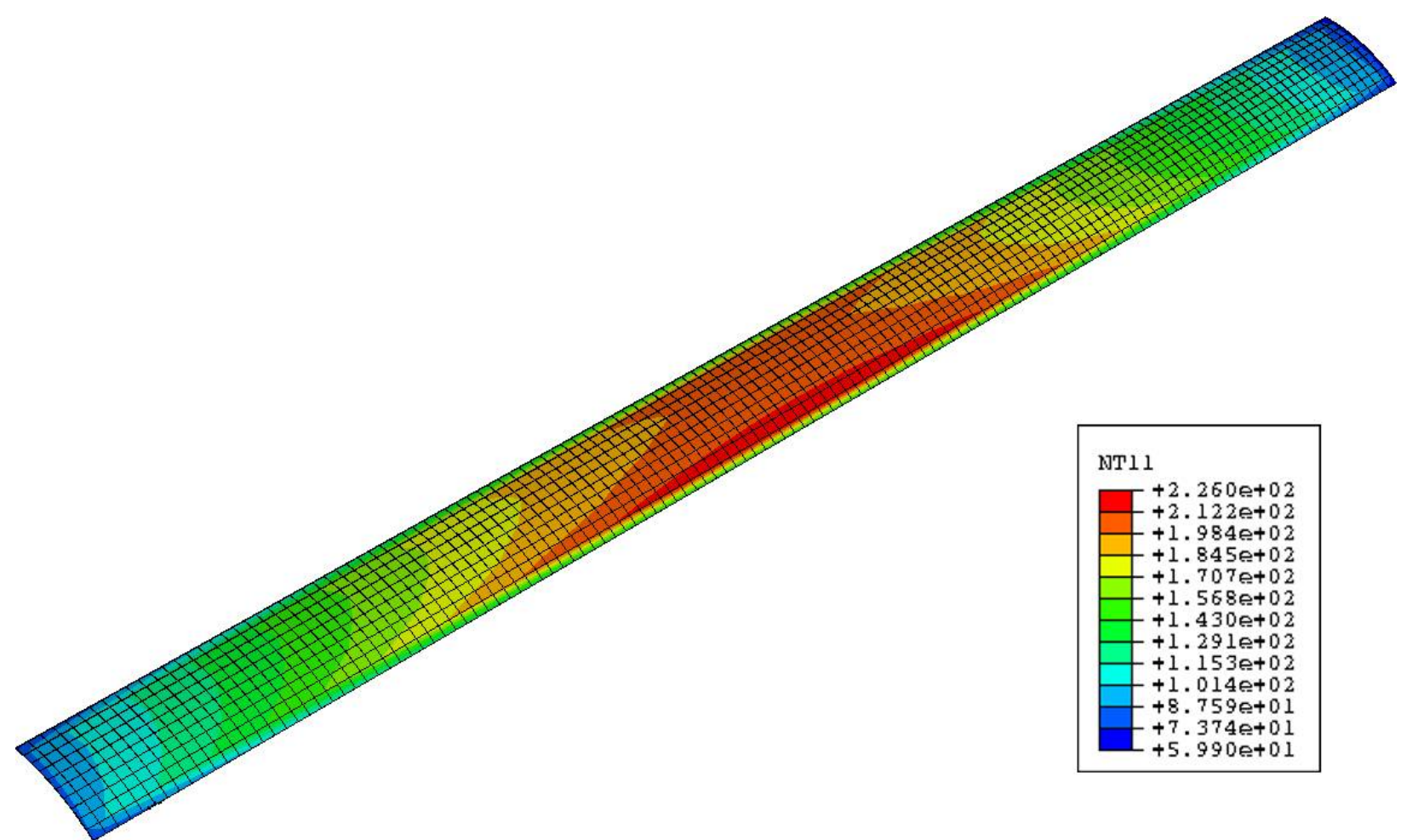

Figure 18. Temperature in HEU Plate 16 for Condition 4 Reactivity Insertion 


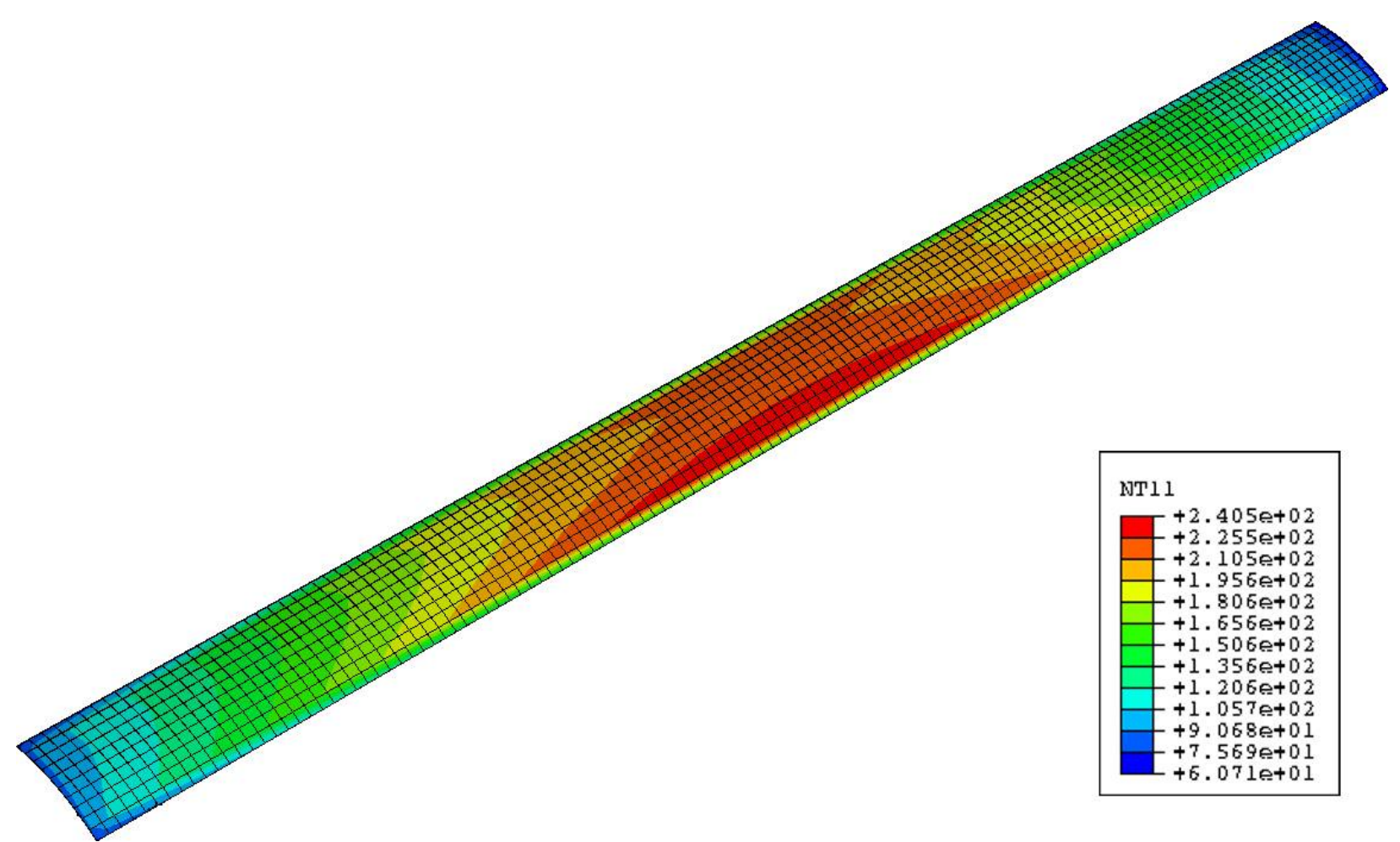

Figure 19. Temperature in HEU Plate 17 for Condition 4 Reactivity Insertion

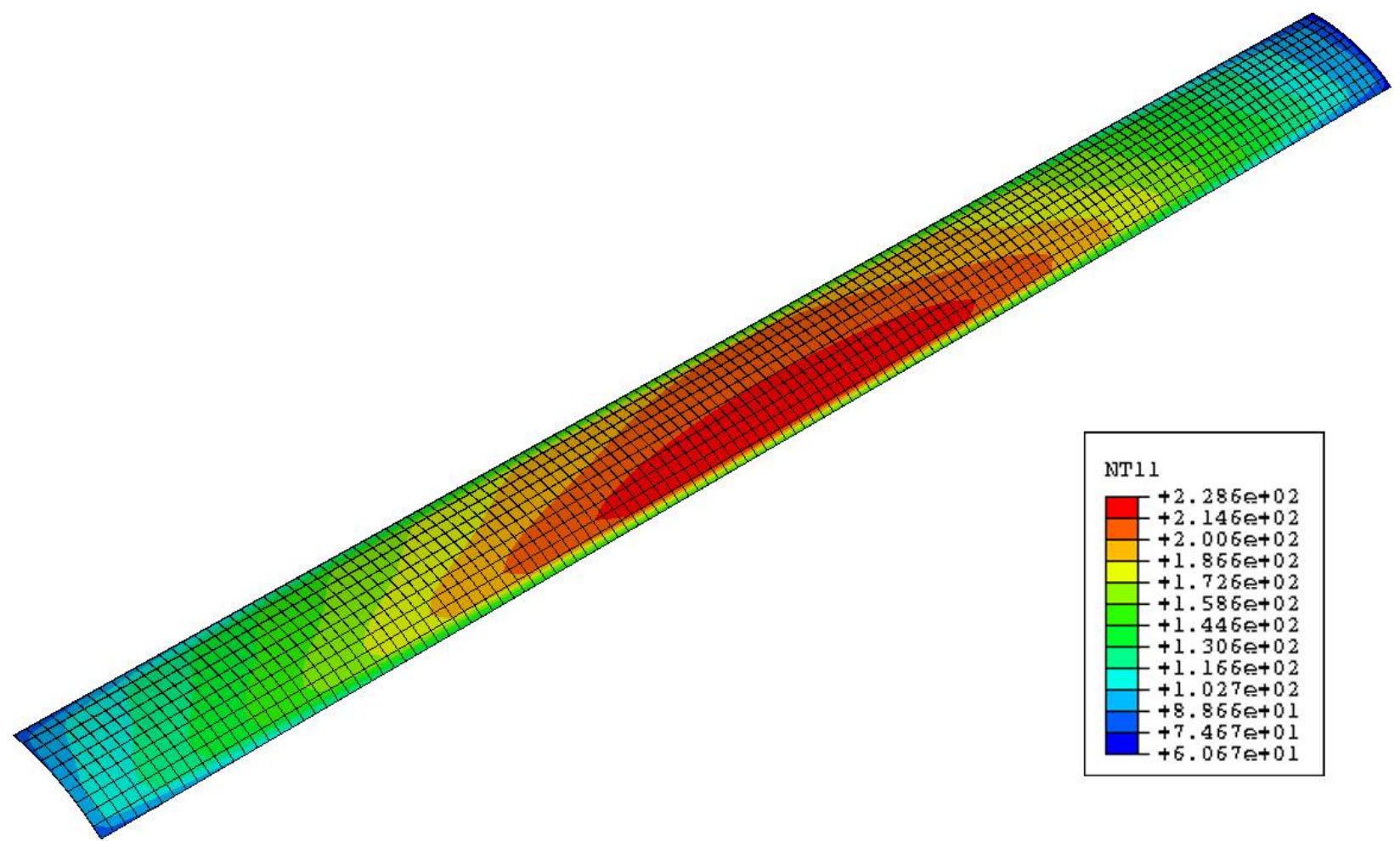

Figure 20. Temperature in HEU Plate 19 for Condition 4 Reactivity Insertion 


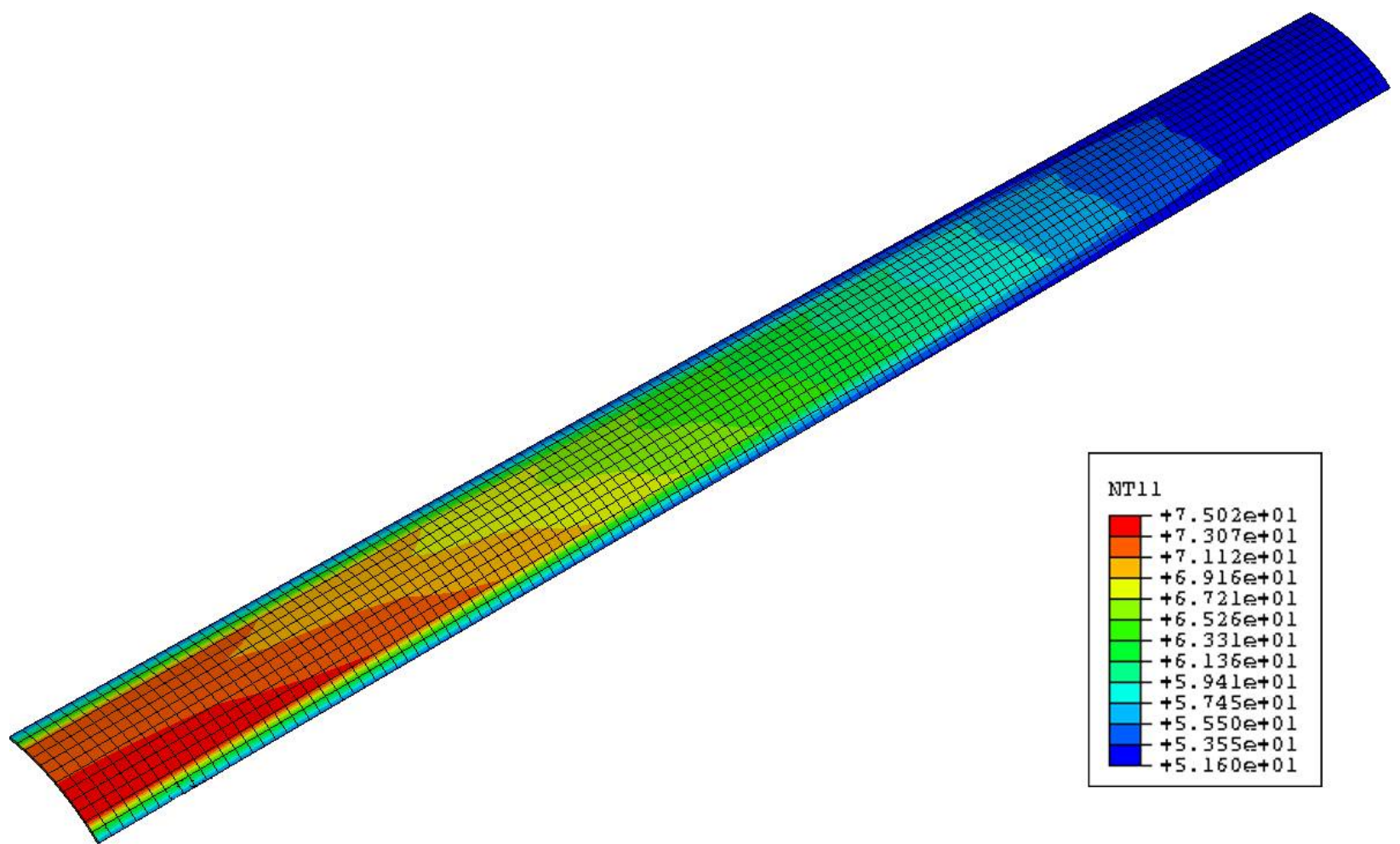

Figure 21. Temperature in Coolant Channel 16 for LEU Fuel, Steady State

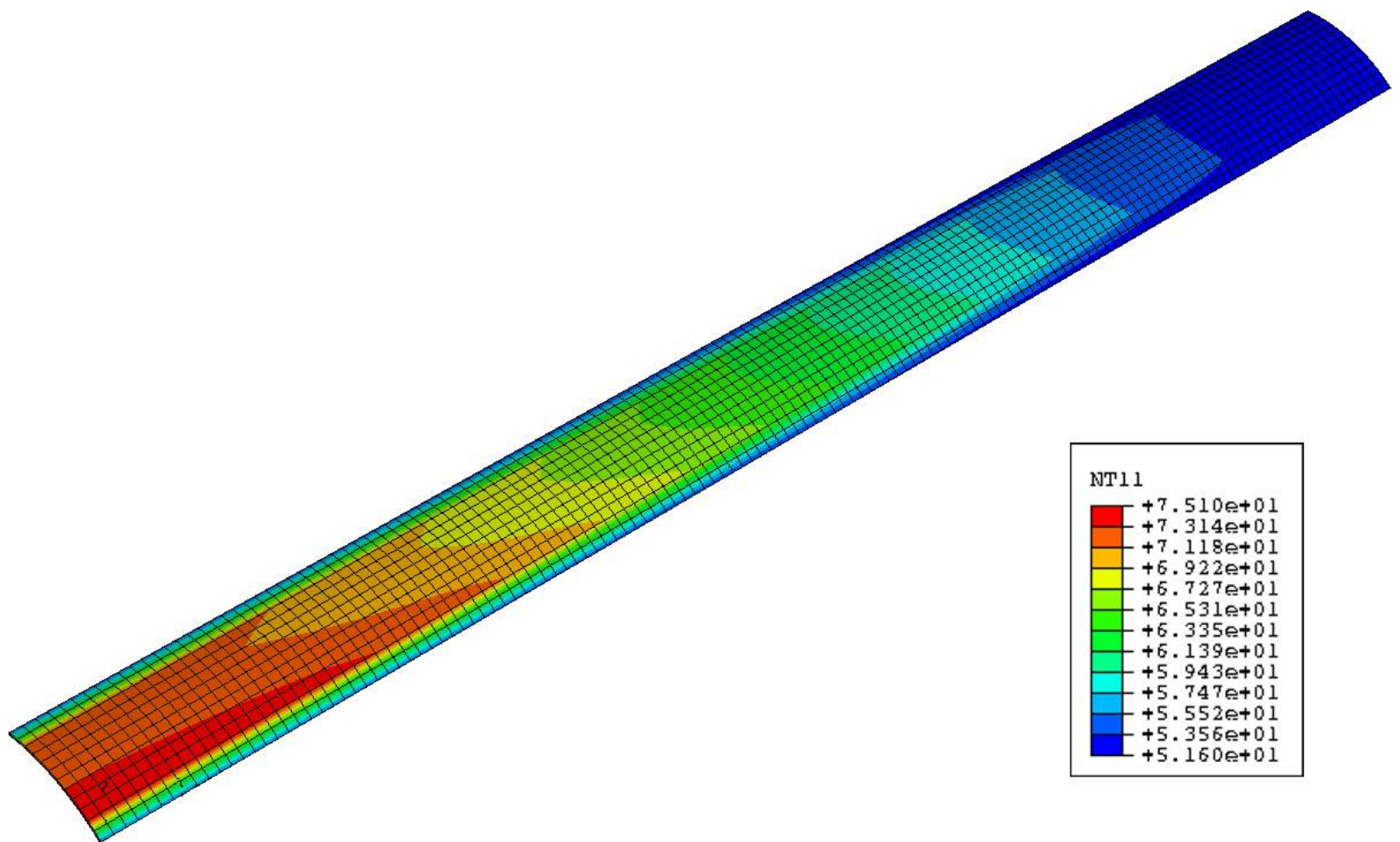

Figure 22. Temperature in Coolant Channel 17 for HEU Fuel, Steady State 


\section{Conclusions and Recommendations}

For this study, the detailed plate-by-plate MCNP ATR $1 / 8^{\text {th }}$ core model was developed and validated. This study also demonstrated that the $1 / 8^{\text {th }}$ core model adequately represents the whole ATR core model for neutronics burnup analysis characterization. The detailed plate-by-plate MCNP ATR $1 / 8^{\text {th }}$ core model used in this study handles complex spectral transitions at the boundaries between the plates in a straight forward manner.

The MCWO-calculated K-eff versus EFPDs results indicate that both LEU Case-C and Case-D provide excess reactivity versus burnup while providing fission heat profiles similar to ATR reference HEU Case-A. The LEU core conversion designer will be able to optimize the U-235 fuel loading so that the K-eff and relative radial fission heat flux profile are similar to Case-A, the current HEU fuel type. To achieve the flattened heat flux profile, the LEU core designer can fix the U-235 enrichment of $19.7 \mathrm{wt} \%$ and vary the thickness of the four inner/outer plates, as well as adjust the amount and type of burnable absorber in the four inner/outer plates. As a result, it has been concluded that LEU core conversion for the ATR is feasible.

The LEU core designer can use the detailed plate-by-plate MCNP ATR $1 / 8^{\text {th }}$ core model to optimize the U-235 loading by either minimizing K-eff differences with respect to the HEU core during the 115 EFPDs of operation at a total core power of $115 \mathrm{MW}$ (23 MW per lobe), or by reducing the higher L2AR of heat flux at the inner/outer plates. However, to demonstrate that the LEU core fuel cycle performance can meet the UFSAR safety requirement, a further study will be necessary in order to investigate the detailed radial, axial, and azimuthal heat flux profile variations versus EFPDs.

To demonstrate that the LEU core fuel cycle performance can meet the Updated Final Safety Analysis Report (UFSAR) safety requirements, additional studies will be necessary to evaluate and compare safety parameters such as void reactivity and Doppler coefficients, control components worth (outer shim control cylinders, safety rods and regulating rod), and shutdown margins between the HEU and LEU cores. 


\section{References}

1. Roth, P. A., 2004a, letter to J. D. Abrashoff, PAR-17-04, revision 1, "Startup Outer Shim Prediction for ATR Cycle 134A-1, Revision 1," December 20, 2004.

2. ASUDAS report from DAC Hourly Control History for Cycle 134A-1/A-2 End of Cycle; provided by email from D. V. Thomas to M. A. Lillo, July 11, 2005.

3. Cook W. C., Smith A. C., "ATR CSAP Package on the Workstation Version 1," PG-T-96002, May, 1996.

4. G. S. Chang, "MCWO - LINKING MCNP AND ORIGEN2 FOR FUEL BURNUP ANALYSIS," Proceedings of 'The Monte Carlo Method: Versatility Unbounded In A Dynamic Computing World,' Chattanooga, Tennessee, April 17-21, 2005, on CD-ROM, American Nuclear Society, LaGrange Park, IL (2005).

5. Tim Goorley, Jeff Bull, Forrest Brown, et. al., "Release of MCNP5_RSICC_1.30," MCNP Monte Carlo Team X-5, LA-UR-04-4519, Los Alamos National Laboratory, November 2004.

6. X-5 Monte Carlo Team, "MCNP-A General Monte Carlo N-Particle Transport Code, Version 5," Volume I (LA-UR-03-1987) and Volume II (LA-CP-0245), Los Alamos National Laboratory April 24, 2003 (Revised 6/30/2004).

7. G. Croff, "ORIGEN2: A Versatile Computer Code for Calculating the Nuclide Compositions and Characteristics of Nuclear Materials, Nuclear Technology," Vol. 62, pp. 335-352, 1983.

8. G. S. Chang and J. M. Ryskamp, "Depletion Analysis of Mixed Oxide Fuel Pins in Light Water Reactors and the Advanced Test Reactor," Nucl. Technol., Vol. 129, No. 3, p. 326-337 (2000). 


\section{Appendix A}

Table A-1. ATR reference HEU fuel assembly radial power profile (0.66 g B-10 in inner/outer 4 plates).

\begin{tabular}{|c|c|c|c|c|c|c|c|c|}
\hline \multicolumn{9}{|l|}{ FE-16 } \\
\hline $\begin{array}{l}\text { Plate } \\
\text { ID }\end{array}$ & $(W / g)$ & (W/cc) & $\left(\mathrm{W} / \mathrm{cm}^{2}\right)$ & $\begin{array}{c}\text { P/A } \\
(\mathrm{W} / \mathrm{g})\end{array}$ & $\begin{array}{c}\text { P/A } \\
(\mathrm{W} / \mathrm{cc})\end{array}$ & $\begin{array}{c}\mathrm{P} / \mathrm{A} \\
\left(\mathrm{W} / \mathrm{cm}^{2}\right)\end{array}$ & $\begin{array}{l}\text { Density } \\
\text { (g/cc) }\end{array}$ & $\begin{array}{l}\text { Thickness } \\
\text { (in.) }\end{array}$ \\
\hline Plate-1 & 792.69 & 3087.47 & 78.42 & 1.19 & 1.07 & 1.07 & 3.89 & 0.020 \\
\hline Plate-2 & 686.75 & 2635.03 & 66.93 & 1.03 & 0.92 & 0.92 & 3.84 & 0.020 \\
\hline Plate-3 & 697.79 & 2928.36 & 74.38 & 1.05 & 1.02 & 1.02 & 4.20 & 0.020 \\
\hline Plate-4 & 642.69 & 2689.57 & 68.32 & 0.97 & 0.94 & 0.94 & 4.18 & 0.020 \\
\hline Plate-5 & 667.45 & 3059.00 & 77.70 & 1.00 & 1.06 & 1.06 & 4.58 & 0.020 \\
\hline Plate-6 & 659.00 & 3020.29 & 76.72 & 0.99 & 1.05 & 1.05 & 4.58 & 0.020 \\
\hline Plate-7 & 628.96 & 2882.60 & 73.22 & 0.95 & 1.00 & 1.00 & 4.58 & 0.020 \\
\hline Plate-8 & 612.53 & 2807.32 & 71.31 & 0.92 & 0.98 & 0.98 & 4.58 & 0.020 \\
\hline Plate-9 & 607.45 & 2784.02 & 70.71 & 0.91 & 0.97 & 0.97 & 4.58 & 0.020 \\
\hline Plate-10 & 597.45 & 2738.19 & 69.55 & 0.90 & 0.95 & 0.95 & 4.58 & 0.020 \\
\hline Plate-11 & 592.01 & 2713.28 & 68.92 & 0.89 & 0.94 & 0.94 & 4.58 & 0.020 \\
\hline Plate-12 & 603.00 & 2763.66 & 70.20 & 0.91 & 0.96 & 0.96 & 4.58 & 0.020 \\
\hline Plate-13 & 616.13 & 2823.82 & 71.72 & 0.93 & 0.98 & 0.98 & 4.58 & 0.020 \\
\hline Plate-14 & 631.50 & 2894.24 & 73.51 & 0.95 & 1.01 & 1.01 & 4.58 & 0.020 \\
\hline Plate-15 & 676.98 & 3094.50 & 78.60 & 1.02 & 1.08 & 1.08 & 4.57 & 0.020 \\
\hline Plate-16 & 633.05 & 2651.86 & 67.36 & 0.95 & 0.92 & 0.92 & 4.19 & 0.020 \\
\hline Plate-17 & 701.45 & 2937.16 & 74.60 & 1.05 & 1.02 & 1.02 & 4.19 & 0.020 \\
\hline Plate-18 & 712.02 & 2739.13 & 69.57 & 1.07 & 0.95 & 0.95 & 3.85 & 0.020 \\
\hline Plate-19 & 879.80 & 3393.55 & 86.20 & 1.32 & 1.18 & 1.18 & 3.86 & 0.020 \\
\hline Average & 665.20 & 2875.95 & 73.05 & & & & & \\
\hline \multicolumn{9}{|l|}{ FE-17 } \\
\hline $\begin{array}{l}\text { Plate } \\
\text { ID }\end{array}$ & $(W / g)$ & (W/cc) & $\left(\mathrm{W} / \mathrm{cm}^{2}\right)$ & $\begin{array}{c}\text { P/A } \\
\text { (W/g) }\end{array}$ & $\begin{array}{c}\text { P/A } \\
(\mathrm{W} / \mathrm{cc})\end{array}$ & $\begin{array}{c}\mathrm{P} / \mathrm{A} \\
\left(\mathrm{W} / \mathrm{cm}^{2}\right)\end{array}$ & $\begin{array}{l}\text { Density } \\
\text { (g/cc) }\end{array}$ & $\begin{array}{l}\text { Thickness } \\
\text { (in.) }\end{array}$ \\
\hline Plate-1 & 836.33 & 3257.47 & 82.74 & 1.16 & 1.05 & 1.05 & 3.89 & 0.0200 \\
\hline Plate-2 & 722.43 & 2771.93 & 70.41 & 1.00 & 0.89 & 0.89 & 3.84 & 0.0200 \\
\hline Plate-3 & 745.32 & 3127.84 & 79.45 & 1.04 & 1.00 & 1.00 & 4.20 & 0.0200 \\
\hline Plate-4 & 671.46 & 2809.96 & 71.37 & 0.93 & 0.90 & 0.90 & 4.18 & 0.0200 \\
\hline Plate-5 & 709.80 & 3253.10 & 82.63 & 0.99 & 1.04 & 1.04 & 4.58 & 0.0200 \\
\hline Plate-6 & 708.99 & 3249.40 & 82.53 & 0.98 & 1.04 & 1.04 & 4.58 & 0.0200 \\
\hline Plate-7 & 670.36 & 3072.35 & 78.04 & 0.93 & 0.99 & 0.99 & 4.58 & 0.0200 \\
\hline Plate-8 & 658.29 & 3017.04 & 76.63 & 0.91 & 0.97 & 0.97 & 4.58 & 0.0200 \\
\hline Plate-9 & 657.12 & 3011.67 & 76.50 & 0.91 & 0.97 & 0.97 & 4.58 & 0.0200 \\
\hline Plate-10 & 654.76 & 3000.86 & 76.22 & 0.91 & 0.96 & 0.96 & 4.58 & 0.0200 \\
\hline Plate-11 & 646.89 & 2964.79 & 75.31 & 0.90 & 0.95 & 0.95 & 4.58 & 0.0200 \\
\hline Plate-12 & 656.78 & 3010.11 & 76.46 & 0.91 & 0.97 & 0.97 & 4.58 & 0.0200 \\
\hline Plate-13 & 669.01 & 3066.16 & 77.88 & 0.93 & 0.98 & 0.98 & 4.58 & 0.0200 \\
\hline Plate-14 & 696.19 & 3190.72 & 81.04 & 0.97 & 1.02 & 1.02 & 4.58 & 0.0200 \\
\hline Plate-15 & 732.17 & 3346.74 & 85.01 & 1.02 & 1.07 & 1.07 & 4.57 & 0.0200 \\
\hline
\end{tabular}




$\begin{array}{lllllllll}\text { Plate-16 } & 709.95 & 2974.00 & 75.54 & 0.99 & 0.96 & 0.96 & 4.19 & 0.0200 \\ \text { Plate-17 } & 783.95 & 3282.59 & 83.38 & 1.09 & 1.05 & 1.05 & 4.19 & 0.0200 \\ \text { Plate-18 } & 781.57 & 3006.68 & 76.37 & 1.09 & 0.97 & 0.97 & 3.85 & 0.0200 \\ \text { Plate-19 } & 969.19 & 3738.38 & 94.95 & 1.35 & 1.20 & 1.20 & 3.86 & 0.0200 \\ \text { Average } & 720.03 & 3113.25 & 79.08 & & & & & \end{array}$

$\begin{array}{ccccccccc}\text { FE-18 } & & & & & & & \\ \text { Plate } & & & & \text { P/A } & \text { P/A } & \text { P/A } & \text { Density } \\ \text { ID } & (\mathrm{W} / \mathrm{g}) & (\mathrm{W} / \mathrm{cc}) & \left(\mathrm{W} / \mathrm{cm}^{2}\right) & (\mathrm{W} / \mathrm{g}) & \begin{array}{c}\text { Thickness } \\ (\mathrm{W} / \mathrm{cc})\end{array} & \begin{array}{c}\left.\text { (W/cm }{ }^{2}\right) \\ (\mathrm{g} / \mathrm{cc})\end{array} \\ \text { Plate-1 } & 951.59 & 3706.40 & 94.14 & 1.14 & 1.03 & 1.03 & 3.89 & 0.0200 \\ \text { Plate-2 } & 835.30 & 3204.99 & 81.41 & 1.00 & 0.89 & 0.89 & 3.84 & 0.0200 \\ \text { Plate-3 } & 851.82 & 3574.75 & 90.80 & 1.02 & 0.99 & 0.99 & 4.20 & 0.0200 \\ \text { Plate-4 } & 784.61 & 3283.46 & 83.40 & 0.94 & 0.91 & 0.91 & 4.18 & 0.0200 \\ \text { Plate-5 } & 817.31 & 3745.87 & 95.14 & 0.98 & 1.04 & 1.04 & 4.58 & 0.0200 \\ \text { Plate-6 } & 797.82 & 3656.54 & 92.88 & 0.95 & 1.01 & 1.01 & 4.58 & 0.0200 \\ \text { Plate-7 } & 768.74 & 3523.23 & 89.49 & 0.92 & 0.98 & 0.98 & 4.58 & 0.0200 \\ \text { Plate-8 } & 755.24 & 3461.35 & 87.92 & 0.90 & 0.96 & 0.96 & 4.58 & 0.0200 \\ \text { Plate-9 } & 737.36 & 3379.44 & 85.84 & 0.88 & 0.94 & 0.94 & 4.58 & 0.0200 \\ \text { Plate-10 } & 741.17 & 3396.91 & 86.28 & 0.89 & 0.94 & 0.94 & 4.58 & 0.0200 \\ \text { Plate-11 } & 753.85 & 3455.01 & 87.76 & 0.90 & 0.96 & 0.96 & 4.58 & 0.0200 \\ \text { Plate-12 } & 760.58 & 3485.84 & 88.54 & 0.91 & 0.96 & 0.96 & 4.58 & 0.0200 \\ \text { Plate-13 } & 787.55 & 3609.43 & 91.68 & 0.94 & 1.00 & 1.00 & 4.58 & 0.0200 \\ \text { Plate-14 } & 823.32 & 3773.41 & 95.84 & 0.99 & 1.04 & 1.04 & 4.58 & 0.0200 \\ \text { Plate-15 } & 874.54 & 3997.52 & 101.54 & 1.05 & 1.11 & 1.11 & 4.57 & 0.0200 \\ \text { Plate-16 } & 826.03 & 3460.24 & 87.89 & 0.99 & 0.96 & 0.96 & 4.19 & 0.0200 \\ \text { Plate-17 } & 918.71 & 3846.88 & 97.71 & 1.10 & 1.06 & 1.06 & 4.19 & 0.0200 \\ \text { Plate-18 } & 928.36 & 3571.39 & 90.71 & 1.11 & 0.99 & 0.99 & 3.85 & 0.0200 \\ \text { Plate-19 } & 1167.35 & 4502.72 & 114.37 & 1.40 & 1.25 & 1.25 & 3.86 & 0.0200 \\ \text { Average } & 835.86 & 3612.39 & 91.75 & & & & & \end{array}$

$\begin{array}{ccccccccc}\begin{array}{c}\text { FE-19 } \\ \text { Plate } \\ \text { ID }\end{array} & (\mathrm{W} / \mathrm{g}) & (\mathrm{W} / \mathrm{cc}) & \left(\mathrm{W} / \mathrm{cm}^{2}\right) & \begin{array}{c}\mathrm{P} / \mathrm{A} \\ (\mathrm{W} / \mathrm{g})\end{array} & \begin{array}{c}\text { P/A } \\ (\mathrm{W} / \mathrm{cc})\end{array} & \begin{array}{c}\mathrm{P} / \mathrm{A} \\ \left(\mathrm{W} / \mathrm{cm}^{2}\right)\end{array} & \begin{array}{c}\text { Density } \\ (\mathrm{g} / \mathrm{cc})\end{array} & \begin{array}{c}\text { Thickness } \\ (\mathrm{in} .)\end{array} \\ \text { Plate-1 } & 1121.75 & 4369.15 & 110.98 & 1.19 & 1.07 & 1.07 & 3.89 & 0.0200 \\ \text { Plate-2 } & 947.84 & 3636.81 & 92.37 & 1.01 & 0.89 & 0.89 & 3.84 & 0.0200 \\ \text { Plate-3 } & 975.36 & 4093.24 & 103.97 & 1.04 & 1.01 & 1.01 & 4.20 & 0.0200 \\ \text { Plate-4 } & 887.12 & 3712.47 & 94.30 & 0.94 & 0.91 & 0.91 & 4.18 & 0.0200 \\ \text { Plate-5 } & 923.83 & 4234.03 & 107.54 & 0.98 & 1.04 & 1.04 & 4.58 & 0.0200 \\ \text { Plate-6 } & 915.34 & 4195.15 & 106.56 & 0.97 & 1.03 & 1.03 & 4.58 & 0.0200 \\ \text { Plate-7 } & 871.83 & 3995.72 & 101.49 & 0.93 & 0.98 & 0.98 & 4.58 & 0.0200 \\ \text { Plate-8 } & 863.63 & 3958.15 & 100.54 & 0.92 & 0.97 & 0.97 & 4.58 & 0.0200 \\ \text { Plate-9 } & 850.58 & 3898.33 & 99.02 & 0.90 & 0.96 & 0.96 & 4.58 & 0.0200 \\ \text { Plate-10 } & 856.23 & 3924.23 & 99.68 & 0.91 & 0.97 & 0.97 & 4.58 & 0.0200 \\ \text { Plate-11 } & 856.57 & 3925.78 & 99.71 & 0.91 & 0.97 & 0.97 & 4.58 & 0.0200 \\ \text { Plate-12 } & 869.93 & 3986.99 & 101.27 & 0.93 & 0.98 & 0.98 & 4.58 & 0.0200 \\ \text { Plate-13 } & 893.38 & 4094.50 & 104.00 & 0.95 & 1.01 & 1.01 & 4.58 & 0.0200\end{array}$




$\begin{array}{lcccccccc}\text { Plate-14 } & 921.38 & 4222.82 & 107.26 & 0.98 & 1.04 & 1.04 & 4.58 & 0.0200 \\ \text { Plate-15 } & 974.54 & 4454.65 & 113.15 & 1.04 & 1.10 & 1.10 & 4.57 & 0.0200 \\ \text { Plate-16 } & 920.23 & 3854.82 & 97.91 & 0.98 & 0.95 & 0.95 & 4.19 & 0.0200 \\ \text { Plate-17 } & 1012.64 & 4240.18 & 107.70 & 1.08 & 1.04 & 1.04 & 4.19 & 0.0200 \\ \text { Plate-18 } & 1000.30 & 3848.15 & 97.74 & 1.06 & 0.95 & 0.95 & 3.85 & 0.0200 \\ \text { Plate-19 } & 1197.28 & 4618.16 & 117.30 & 1.27 & 1.14 & 1.14 & 3.86 & 0.0200 \\ \text { Average } & 939.99 & 4066.49 & 103.29 & & & & & \end{array}$

$\begin{array}{ccccccccc}\text { FE-20 } & & & & & & & \\ \text { Plate } & & & & \text { P/A } & \text { P/A } & \text { Density } & \text { Thickness } \\ \text { ID } & (\mathrm{W} / \mathrm{g}) & (\mathrm{W} / \mathrm{cc}) & \left(\mathrm{W} / \mathrm{cm}^{2}\right) & (\mathrm{W} / \mathrm{g}) & (\mathrm{W} / \mathrm{cc}) & \left(\mathrm{W} / \mathrm{cm}^{2}\right) & \begin{array}{c}\text { (g/cc) } \\ \text { (in.) }\end{array} \\ \text { Plate-1 } & 1120.81 & 4365.49 & 110.88 & 1.19 & 1.07 & 1.00 & 3.89 & 0.0200 \\ \text { Plate-2 } & 972.35 & 3730.86 & 94.76 & 1.03 & 0.92 & 0.85 & 3.84 & 0.0200 \\ \text { Plate-3 } & 1004.66 & 4216.17 & 107.09 & 1.07 & 1.04 & 0.96 & 4.20 & 0.0200 \\ \text { Plate-4 } & 938.41 & 3927.12 & 99.75 & 1.00 & 0.97 & 0.90 & 4.18 & 0.0200 \\ \text { Plate-5 } & 995.34 & 4561.78 & 115.87 & 1.06 & 1.12 & 1.04 & 4.58 & 0.0200 \\ \text { Plate-6 } & 985.36 & 4516.05 & 114.71 & 1.05 & 1.11 & 1.03 & 4.58 & 0.0200 \\ \text { Plate-7 } & 966.64 & 4430.24 & 112.53 & 1.03 & 1.09 & 1.01 & 4.58 & 0.0200 \\ \text { Plate-8 } & 950.79 & 4357.62 & 110.68 & 1.01 & 1.07 & 0.99 & 4.58 & 0.0200 \\ \text { Plate-9 } & 946.72 & 4338.95 & 110.21 & 1.01 & 1.07 & 0.99 & 4.58 & 0.0200 \\ \text { Plate-10 } & 944.13 & 4327.08 & 109.91 & 1.00 & 1.06 & 0.99 & 4.58 & 0.0200 \\ \text { Plate-11 } & 945.89 & 4335.16 & 110.11 & 1.01 & 1.07 & 0.99 & 4.58 & 0.0200 \\ \text { Plate-12 } & 962.53 & 4411.40 & 112.05 & 1.02 & 1.08 & 1.01 & 4.58 & 0.0200 \\ \text { Plate-13 } & 986.73 & 4522.33 & 114.87 & 1.05 & 1.11 & 1.03 & 4.58 & 0.0200 \\ \text { Plate-14 } & 1019.87 & 4674.20 & 118.72 & 1.08 & 1.15 & 1.07 & 4.58 & 0.0200 \\ \text { Plate-15 } & 1053.94 & 4817.58 & 122.37 & 1.12 & 1.18 & 1.10 & 4.57 & 0.0200 \\ \text { Plate-16 } & 998.88 & 4184.30 & 106.28 & 1.06 & 1.03 & 0.95 & 4.19 & 0.0200 \\ \text { Plate-17 } & 1088.32 & 4557.06 & 115.75 & 1.16 & 1.12 & 1.04 & 4.19 & 0.0200 \\ \text { Plate-18 } & 1071.67 & 4122.68 & 104.72 & 1.14 & 1.01 & 0.94 & 3.85 & 0.0200 \\ \text { Plate-19 } & 1278.96 & 4933.21 & 125.30 & 1.36 & 1.21 & 1.12 & 3.86 & 0.0200 \\ \text { Average } & 1012.21 & 4385.75 & 111.40 & & & & & \end{array}$


Table A-2. Optimized LEU (Case-C) U-10Mo fuel assembly radial power profile with $0.8 \mathrm{~g}$ of B-10 in inner/outer 4 plates (Optimized with fixed $19.7 \mathrm{wt} \% \mathrm{U}-235$ and varying fuel meat thickness).

$\begin{array}{ccccccccc}\begin{array}{c}\text { FE-16 } \\ \text { Plate }\end{array} & & & & & & & \\ \text { ID } & (\mathrm{W} / \mathrm{g}) & (\mathrm{W} / \mathrm{cc}) & \left(\mathrm{W} / \mathrm{cm}^{2}\right) & \begin{array}{c}\mathrm{P} / \mathrm{A} / \mathrm{g}) \\ (\mathrm{W} / \mathrm{cc})\end{array} & \begin{array}{c}\mathrm{P} / \mathrm{A} \\ \left(\mathrm{W} / \mathrm{cm}^{2}\right)\end{array} & \begin{array}{c}\text { Density } \\ (\mathrm{g} / \mathrm{cc})\end{array} & \begin{array}{c}\text { Thickness } \\ \text { (in.) }\end{array} \\ \text { Plate-1 } & 421.37 & 7110.14 & 70.43 & 1.48 & 1.48 & 1.04 & 16.87 & 0.0078 \\ \text { Plate-2 } & 337.43 & 5693.80 & 75.20 & 1.19 & 1.19 & 1.11 & 16.87 & 0.0104 \\ \text { Plate-3 } & 297.31 & 5016.80 & 74.54 & 1.05 & 1.05 & 1.10 & 16.87 & 0.0117 \\ \text { Plate-4 } & 276.61 & 4667.61 & 69.36 & 0.97 & 0.97 & 1.02 & 16.87 & 0.0117 \\ \text { Plate-5 } & 255.44 & 4310.31 & 71.16 & 0.90 & 0.90 & 1.05 & 16.87 & 0.0130 \\ \text { Plate-6 } & 242.71 & 4095.46 & 67.62 & 0.86 & 0.86 & 1.00 & 16.87 & 0.0130 \\ \text { Plate-7 } & 233.71 & 3943.58 & 65.11 & 0.82 & 0.82 & 0.96 & 16.87 & 0.0130 \\ \text { Plate-8 } & 228.84 & 3861.39 & 63.75 & 0.81 & 0.81 & 0.94 & 16.87 & 0.0130 \\ \text { Plate-9 } & 224.43 & 3787.05 & 62.52 & 0.79 & 0.79 & 0.92 & 16.87 & 0.0130 \\ \text { Plate-10 } & 222.25 & 3750.33 & 61.92 & 0.78 & 0.78 & 0.91 & 16.87 & 0.0130 \\ \text { Plate-11 } & 222.16 & 3748.68 & 61.89 & 0.78 & 0.78 & 0.91 & 16.87 & 0.0130 \\ \text { Plate-12 } & 226.07 & 3814.66 & 62.98 & 0.80 & 0.80 & 0.93 & 16.87 & 0.0130 \\ \text { Plate-13 } & 231.47 & 3905.80 & 64.48 & 0.82 & 0.82 & 0.95 & 16.87 & 0.0130 \\ \text { Plate-14 } & 243.41 & 4107.28 & 67.81 & 0.86 & 0.86 & 1.00 & 16.87 & 0.0130 \\ \text { Plate-15 } & 260.31 & 4392.42 & 72.52 & 0.92 & 0.92 & 1.07 & 16.87 & 0.0130 \\ \text { Plate-16 } & 287.59 & 4852.82 & 72.11 & 1.01 & 1.01 & 1.07 & 16.87 & 0.0117 \\ \text { Plate-17 } & 328.77 & 5547.69 & 73.27 & 1.16 & 1.16 & 1.08 & 16.87 & 0.0104 \\ \text { Plate-18 } & 387.97 & 6546.68 & 64.85 & 1.37 & 1.37 & 0.96 & 16.87 & 0.0078 \\ \text { Plate-19 } & 463.53 & 7821.66 & 64.57 & 1.63 & 1.63 & 0.95 & 16.87 & 0.0065 \\ \text { Average } & 283.76 & 4788.11 & 67.69 & & & & & \end{array}$

\begin{tabular}{|c|c|c|c|c|c|c|c|c|}
\hline \multicolumn{9}{|l|}{ FE-17 } \\
\hline $\begin{array}{l}\text { Plate } \\
\text { ID }\end{array}$ & $(\mathrm{W} / \mathrm{g})$ & (W/cc) & $\left(\mathrm{W} / \mathrm{cm}^{2}\right)$ & $\begin{array}{c}\text { P/A } \\
\text { (W/g) }\end{array}$ & $\begin{array}{c}\text { P/A } \\
\text { (W/cc) }\end{array}$ & $\begin{array}{c}\text { P/A } \\
\left(\mathrm{W} / \mathrm{cm}^{2}\right)\end{array}$ & $\begin{array}{c}\text { Density } \\
\text { (g/cc) }\end{array}$ & $\begin{array}{l}\text { Thickness } \\
\text { (in.) }\end{array}$ \\
\hline Plate-1 & 453.00 & 7643.90 & 75.72 & 1.46 & 1.46 & 1.02 & 16.87 & 0.0078 \\
\hline Plate-2 & 359.95 & 6073.77 & 80.22 & 1.16 & 1.16 & 1.08 & 16.87 & 0.0104 \\
\hline Plate-3 & 318.54 & 5375.02 & 79.87 & 1.03 & 1.03 & 1.08 & 16.87 & 0.0117 \\
\hline Plate-4 & 297.33 & 5017.20 & 74.55 & 0.96 & 0.96 & 1.01 & 16.87 & 0.0117 \\
\hline Plate-5 & 275.94 & 4656.26 & 76.87 & 0.89 & 0.89 & 1.04 & 16.87 & 0.0130 \\
\hline Plate-6 & 263.97 & 4454.27 & 73.54 & 0.85 & 0.85 & 0.99 & 16.87 & 0.0130 \\
\hline Plate-7 & 254.71 & 4297.95 & 70.96 & 0.82 & 0.82 & 0.96 & 16.87 & 0.0130 \\
\hline Plate-8 & 248.98 & 4201.33 & 69.36 & 0.80 & 0.80 & 0.94 & 16.87 & 0.0130 \\
\hline Plate-9 & 245.42 & 4141.16 & 68.37 & 0.79 & 0.79 & 0.92 & 16.87 & 0.0130 \\
\hline Plate-10 & 244.96 & 4133.43 & 68.24 & 0.79 & 0.79 & 0.92 & 16.87 & 0.0130 \\
\hline Plate-11 & 245.17 & 4137.05 & 68.30 & 0.79 & 0.79 & 0.92 & 16.87 & 0.0130 \\
\hline Plate-12 & 250.04 & 4219.17 & 69.66 & 0.81 & 0.81 & 0.94 & 16.87 & 0.0130 \\
\hline Plate-13 & 256.94 & 4335.69 & 71.58 & 0.83 & 0.83 & 0.97 & 16.87 & 0.0130 \\
\hline Plate-14 & 268.46 & 4530.05 & 74.79 & 0.86 & 0.86 & 1.01 & 16.87 & 0.0130 \\
\hline Plate-15 & 287.02 & 4843.27 & 79.96 & 0.92 & 0.92 & 1.08 & 16.87 & 0.0130 \\
\hline Plate-16 & 317.56 & 5358.52 & 79.62 & 1.02 & 1.02 & 1.08 & 16.87 & 0.0117 \\
\hline Plate-17 & 366.03 & 6176.46 & 81.58 & 1.18 & 1.18 & 1.10 & 16.87 & 0.0104 \\
\hline
\end{tabular}




$\begin{array}{lllllllll}\text { Plate-18 } & 430.04 & 7256.46 & 71.88 & 1.38 & 1.38 & 0.97 & 16.87 & 0.0078 \\ \text { Plate-19 } & 515.66 & 8701.20 & 71.83 & 1.66 & 1.66 & 0.97 & 16.87 & 0.0065 \\ \text { Average } & 310.51 & 5239.59 & 74.05 & & & & & \end{array}$

$\begin{array}{ccccccccc}\begin{array}{c}\text { FE-18 } \\ \text { Plate }\end{array} & & & & & & & \\ \text { ID } & (\mathrm{W} / \mathrm{g}) & (\mathrm{W} / \mathrm{cc}) & \left(\mathrm{W} / \mathrm{cm}^{2}\right) & \begin{array}{c}\mathrm{P} / \mathrm{A} \\ (\mathrm{W} / \mathrm{g})\end{array} & \begin{array}{c}\mathrm{P} / \mathrm{A} \\ (\mathrm{W} / \mathrm{cc})\end{array} & \begin{array}{c}\mathrm{P} / \mathrm{A} \\ \left(\mathrm{W} / \mathrm{cm}^{2}\right)\end{array} & \begin{array}{c}\text { Density } \\ (\mathrm{g} / \mathrm{cc})\end{array} & \begin{array}{c}\text { Thickness } \\ \text { (in.) }\end{array} \\ \text { Plate-1 } & 512.49 & 8647.71 & 85.66 & 1.41 & 1.41 & 0.99 & 16.87 & 0.0078 \\ \text { Plate-2 } & 409.52 & 6910.34 & 91.27 & 1.13 & 1.13 & 1.06 & 16.87 & 0.0104 \\ \text { Plate-3 } & 364.49 & 6150.52 & 91.39 & 1.00 & 1.00 & 1.06 & 16.87 & 0.0117 \\ \text { Plate-4 } & 339.80 & 5733.79 & 85.20 & 0.94 & 0.94 & 0.99 & 16.87 & 0.0117 \\ \text { Plate-5 } & 316.31 & 5337.51 & 88.12 & 0.87 & 0.87 & 1.02 & 16.87 & 0.0130 \\ \text { Plate-6 } & 304.21 & 5133.20 & 84.75 & 0.84 & 0.84 & 0.98 & 16.87 & 0.0130 \\ \text { Plate-7 } & 293.73 & 4956.49 & 81.83 & 0.81 & 0.81 & 0.95 & 16.87 & 0.0130 \\ \text { Plate-8 } & 288.63 & 4870.40 & 80.41 & 0.80 & 0.80 & 0.93 & 16.87 & 0.0130 \\ \text { Plate-9 } & 285.17 & 4811.96 & 79.45 & 0.79 & 0.79 & 0.92 & 16.87 & 0.0130 \\ \text { Plate-10 } & 285.68 & 4820.64 & 79.59 & 0.79 & 0.79 & 0.92 & 16.87 & 0.0130 \\ \text { Plate-11 } & 287.45 & 4850.41 & 80.08 & 0.79 & 0.79 & 0.93 & 16.87 & 0.0130 \\ \text { Plate-12 } & 292.82 & 4941.13 & 81.58 & 0.81 & 0.81 & 0.94 & 16.87 & 0.0130 \\ \text { Plate-13 } & 302.25 & 5100.21 & 84.20 & 0.83 & 0.83 & 0.97 & 16.87 & 0.0130 \\ \text { Plate-14 } & 317.15 & 5351.65 & 88.36 & 0.87 & 0.87 & 1.02 & 16.87 & 0.0130 \\ \text { Plate-15 } & 342.28 & 5775.65 & 95.36 & 0.94 & 0.94 & 1.10 & 16.87 & 0.0130 \\ \text { Plate-16 } & 379.68 & 6406.77 & 95.20 & 1.05 & 1.05 & 1.10 & 16.87 & 0.0117 \\ \text { Plate-17 } & 438.27 & 7395.38 & 97.68 & 1.21 & 1.21 & 1.13 & 16.87 & 0.0104 \\ \text { Plate-18 } & 516.32 & 8712.39 & 86.30 & 1.42 & 1.42 & 1.00 & 16.87 & 0.0078 \\ \text { Plate-19 } & 621.67 & 10490.04 & 86.60 & 1.71 & 1.71 & 1.00 & 16.87 & 0.0065 \\ \text { Average } & 363.05 & 6126.11 & 86.47 & & & & & \end{array}$

$\begin{array}{ccccccccc}\begin{array}{c}\text { FE-19 } \\ \text { Plate }\end{array} & & & & & & & \\ \text { ID } & (\mathrm{W} / \mathrm{g}) & (\mathrm{W} / \mathrm{cc}) & \left(\mathrm{W} / \mathrm{cm}^{2}\right) & \begin{array}{c}\mathrm{P} / \mathrm{A} / \mathrm{g}) \\ (\mathrm{W} / \mathrm{cc})\end{array} & \begin{array}{c}\mathrm{P} / \mathrm{A} \\ \left(\mathrm{W} / \mathrm{cm}^{2}\right)\end{array} & \begin{array}{c}\text { Density } \\ (\mathrm{g} / \mathrm{cc})\end{array} & \begin{array}{c}\text { Thickness } \\ \text { (in.) }\end{array} \\ \text { Plate-1 } & 600.46 & 10132.22 & 100.37 & 1.47 & 1.47 & 1.02 & 16.87 & 0.0078 \\ \text { Plate-2 } & 475.67 & 8026.48 & 106.01 & 1.16 & 1.16 & 1.08 & 16.87 & 0.0104 \\ \text { Plate-3 } & 422.47 & 7128.85 & 105.93 & 1.03 & 1.03 & 1.08 & 16.87 & 0.0117 \\ \text { Plate-4 } & 392.91 & 6629.94 & 98.51 & 0.96 & 0.96 & 1.01 & 16.87 & 0.0117 \\ \text { Plate-5 } & 366.35 & 6181.86 & 102.06 & 0.90 & 0.90 & 1.04 & 16.87 & 0.0130 \\ \text { Plate-6 } & 351.40 & 5929.53 & 97.90 & 0.86 & 0.86 & 1.00 & 16.87 & 0.0130 \\ \text { Plate-7 } & 340.85 & 5751.47 & 94.96 & 0.83 & 0.83 & 0.97 & 16.87 & 0.0130 \\ \text { Plate-8 } & 333.97 & 5635.50 & 93.04 & 0.82 & 0.82 & 0.95 & 16.87 & 0.0130 \\ \text { Plate-9 } & 331.39 & 5591.98 & 92.32 & 0.81 & 0.81 & 0.94 & 16.87 & 0.0130 \\ \text { Plate-10 } & 329.37 & 5557.78 & 91.76 & 0.81 & 0.81 & 0.94 & 16.87 & 0.0130 \\ \text { Plate-11 } & 330.95 & 5584.55 & 92.20 & 0.81 & 0.81 & 0.94 & 16.87 & 0.0130 \\ \text { Plate-12 } & 337.47 & 5694.46 & 94.02 & 0.83 & 0.83 & 0.96 & 16.87 & 0.0130 \\ \text { Plate-13 } & 346.12 & 5840.46 & 96.43 & 0.85 & 0.85 & 0.98 & 16.87 & 0.0130 \\ \text { Plate-14 } & 361.87 & 6106.16 & 100.81 & 0.89 & 0.89 & 1.03 & 16.87 & 0.0130 \\ \text { Plate-15 } & 385.53 & 6505.47 & 107.41 & 0.94 & 0.94 & 1.10 & 16.87 & 0.0130\end{array}$




$\begin{array}{lllllllll}\text { Plate-16 } & 420.89 & 7102.14 & 105.53 & 1.03 & 1.03 & 1.08 & 16.87 & 0.0117 \\ \text { Plate-17 } & 472.24 & 7968.62 & 105.25 & 1.16 & 1.16 & 1.07 & 16.87 & 0.0104 \\ \text { Plate-18 } & 540.74 & 9124.55 & 90.39 & 1.32 & 1.32 & 0.92 & 16.87 & 0.0078 \\ \text { Plate-19 } & 625.30 & 10551.38 & 87.10 & 1.53 & 1.53 & 0.89 & 16.87 & 0.0065 \\ \text { Average } & 408.73 & 6897.02 & 98.00 & & & & & \end{array}$

$\begin{array}{ccccccccc}\text { FE-20 } & & & & & & & \\ \text { Plate } & & & & \text { P/A } & \text { P/A } & \begin{array}{c}\text { P/A } \\ (\mathrm{W} / \mathrm{Cm})^{2}\end{array} & \begin{array}{c}\text { Density } \\ (\mathrm{g} / \mathrm{cc})\end{array} & \begin{array}{c}\text { Thickness } \\ \text { (in.) }\end{array} \\ \text { Plate-1 } & 592.83 & 10003.37 & 99.09 & 1.45 & 1.45 & 0.95 & 16.87 & 0.0078 \\ \text { Plate-2 } & 481.07 & 8117.61 & 107.22 & 1.18 & 1.18 & 1.02 & 16.87 & 0.0104 \\ \text { Plate-3 } & 433.06 & 7307.45 & 108.58 & 1.06 & 1.06 & 1.04 & 16.87 & 0.0117 \\ \text { Plate-4 } & 408.02 & 6884.99 & 102.30 & 1.00 & 1.00 & 0.98 & 16.87 & 0.0117 \\ \text { Plate-5 } & 383.36 & 6468.85 & 106.80 & 0.94 & 0.94 & 1.02 & 16.87 & 0.0130 \\ \text { Plate-6 } & 370.87 & 6258.02 & 103.32 & 0.91 & 0.91 & 0.99 & 16.87 & 0.0130 \\ \text { Plate-7 } & 364.12 & 6144.12 & 101.44 & 0.89 & 0.89 & 0.97 & 16.87 & 0.0130 \\ \text { Plate-8 } & 358.59 & 6050.87 & 99.90 & 0.88 & 0.88 & 0.95 & 16.87 & 0.0130 \\ \text { Plate-9 } & 356.14 & 6009.60 & 99.22 & 0.87 & 0.87 & 0.95 & 16.87 & 0.0130 \\ \text { Plate-10 } & 358.41 & 6047.78 & 99.85 & 0.88 & 0.88 & 0.95 & 16.87 & 0.0130 \\ \text { Plate-11 } & 362.19 & 6111.62 & 100.90 & 0.89 & 0.89 & 0.96 & 16.87 & 0.0130 \\ \text { Plate-12 } & 368.85 & 6224.06 & 102.76 & 0.90 & 0.90 & 0.98 & 16.87 & 0.0130 \\ \text { Plate-13 } & 379.68 & 6406.77 & 105.78 & 0.93 & 0.93 & 1.01 & 16.87 & 0.0130 \\ \text { Plate-14 } & 396.86 & 6696.66 & 110.56 & 0.97 & 0.97 & 1.05 & 16.87 & 0.0130 \\ \text { Plate-15 } & 421.75 & 7116.63 & 117.50 & 1.03 & 1.03 & 1.12 & 16.87 & 0.0130 \\ \text { Plate-16 } & 461.60 & 7789.00 & 115.74 & 1.13 & 1.13 & 1.10 & 16.87 & 0.0117 \\ \text { Plate-17 } & 519.76 & 8770.51 & 115.84 & 1.27 & 1.27 & 1.11 & 16.87 & 0.0104 \\ \text { Plate-18 } & 594.13 & 10025.34 & 99.31 & 1.45 & 1.45 & 0.95 & 16.87 & 0.0078 \\ \text { Plate-19 } & 685.55 & 11568.05 & 95.49 & 1.68 & 1.68 & 0.91 & 16.87 & 0.0065 \\ \text { Average } & 436.68 & 7368.49 & 104.82 & & & & & \end{array}$

Table A-3. Optimized LEU U-10Mo fuel assembly radial power profile with $6.918 \mathrm{~g}$ of Cd in inner/outer 4 plates.

\begin{tabular}{|c|c|c|c|c|c|c|c|c|}
\hline \multicolumn{9}{|l|}{ FE-16 } \\
\hline $\begin{array}{l}\text { Plate } \\
\text { ID }\end{array}$ & $(\mathrm{W} / \mathrm{g})$ & (W/cc) & $\left(\mathrm{W} / \mathrm{cm}^{2}\right)$ & $\begin{array}{c}\text { P/A } \\
\text { (W/g) }\end{array}$ & $\begin{array}{c}\text { P/A } \\
(\mathrm{W} / \mathrm{cc})\end{array}$ & $\begin{array}{c}\mathrm{P} / \mathrm{A} \\
\left(\mathrm{W} / \mathrm{cm}^{2}\right)\end{array}$ & $\begin{array}{l}\text { Density } \\
\text { (g/cc) }\end{array}$ & $\begin{array}{l}\text { Thickness } \\
\text { (in.) }\end{array}$ \\
\hline Plate-1 & 432.57 & 7299.21 & 72.31 & 1.50 & 1.50 & 1.05 & 16.87 & 0.0078 \\
\hline Plate-2 & 346.26 & 5842.75 & 77.17 & 1.20 & 1.20 & 1.12 & 16.87 & 0.0104 \\
\hline Plate-3 & 302.58 & 5105.73 & 75.87 & 1.05 & 1.05 & 1.11 & 16.87 & 0.0117 \\
\hline Plate-4 & 278.30 & 4696.02 & 69.78 & 0.96 & 0.96 & 1.02 & 16.87 & 0.0117 \\
\hline Plate-5 & 257.05 & 4337.48 & 71.61 & 0.89 & 0.89 & 1.04 & 16.87 & 0.0130 \\
\hline Plate-6 & 245.33 & 4139.72 & 68.35 & 0.85 & 0.85 & 1.00 & 16.87 & 0.0130 \\
\hline Plate-7 & 236.08 & 3983.58 & 65.77 & 0.82 & 0.82 & 0.96 & 16.87 & 0.0130 \\
\hline
\end{tabular}




$\begin{array}{ccccccccc}\text { Plate-8 } & 229.46 & 3871.93 & 63.93 & 0.80 & 0.80 & 0.93 & 16.87 & 0.0130 \\ \text { Plate-9 } & 225.82 & 3810.47 & 62.91 & 0.78 & 0.78 & 0.92 & 16.87 & 0.0130 \\ \text { Plate-10 } & 224.01 & 3779.88 & 62.41 & 0.78 & 0.78 & 0.91 & 16.87 & 0.0130 \\ \text { Plate-11 } & 224.16 & 3782.44 & 62.45 & 0.78 & 0.78 & 0.91 & 16.87 & 0.0130 \\ \text { Plate-12 } & 227.16 & 3833.04 & 63.28 & 0.79 & 0.79 & 0.92 & 16.87 & 0.0130 \\ \text { Plate-13 } & 232.56 & 3924.26 & 64.79 & 0.81 & 0.81 & 0.94 & 16.87 & 0.0130 \\ \text { Plate-14 } & 243.26 & 4104.76 & 67.77 & 0.84 & 0.84 & 0.99 & 16.87 & 0.0130 \\ \text { Plate-15 } & 261.28 & 4408.92 & 72.79 & 0.91 & 0.91 & 1.06 & 16.87 & 0.0130 \\ \text { Plate-16 } & 290.28 & 4898.22 & 72.78 & 1.01 & 1.01 & 1.06 & 16.87 & 0.0117 \\ \text { Plate-17 } & 336.11 & 5671.55 & 74.91 & 1.17 & 1.17 & 1.09 & 16.87 & 0.0104 \\ \text { Plate-18 } & 401.11 & 6768.42 & 67.05 & 1.39 & 1.39 & 0.98 & 16.87 & 0.0078 \\ \text { Plate-19 } & 487.05 & 8218.47 & 67.84 & 1.69 & 1.69 & 0.99 & 16.87 & 0.0065 \\ \text { Average } & 288.44 & 4867.20 & 68.62 & & & & & \\ & 432.57 & 7299.21 & 72.31 & 1.50 & 1.50 & 1.05 & 16.87 & 0.0078\end{array}$

\begin{tabular}{|c|c|c|c|c|c|c|c|c|}
\hline \multicolumn{9}{|l|}{ FE-17 } \\
\hline $\begin{array}{l}\text { Plate } \\
\text { ID }\end{array}$ & $(\mathrm{W} / \mathrm{g})$ & (W/cc) & $\left(\mathrm{W} / \mathrm{cm}^{2}\right)$ & $\begin{array}{c}\text { P/A } \\
(W / g)\end{array}$ & $\begin{array}{c}P / A \\
\text { (W/cc) }\end{array}$ & $\begin{array}{c}\mathrm{P} / \mathrm{A} \\
\left(\mathrm{W} / \mathrm{cm}^{2}\right)\end{array}$ & $\begin{array}{c}\text { Density } \\
\text { (g/cc) }\end{array}$ & $\begin{array}{l}\text { Thickness } \\
\text { (in.) }\end{array}$ \\
\hline Plate-1 & 462.23 & 7799.67 & 77.26 & 1.46 & 1.46 & 1.03 & 16.87 & 0.0078 \\
\hline Plate-2 & 370.71 & 6255.33 & 82.62 & 1.17 & 1.17 & 1.10 & 16.87 & 0.0104 \\
\hline Plate-3 & 325.14 & 5486.47 & 81.52 & 1.03 & 1.03 & 1.08 & 16.87 & 0.0117 \\
\hline Plate-4 & 299.99 & 5062.11 & 75.22 & 0.95 & 0.95 & 1.00 & 16.87 & 0.0117 \\
\hline Plate-5 & 277.79 & 4687.43 & 77.39 & 0.88 & 0.88 & 1.03 & 16.87 & 0.0130 \\
\hline Plate-6 & 265.76 & 4484.44 & 74.04 & 0.84 & 0.84 & 0.98 & 16.87 & 0.0130 \\
\hline Plate-7 & 256.50 & 4328.24 & 71.46 & 0.81 & 0.81 & 0.95 & 16.87 & 0.0130 \\
\hline Plate-8 & 250.42 & 4225.60 & 69.76 & 0.79 & 0.79 & 0.93 & 16.87 & 0.0130 \\
\hline Plate-9 & 246.84 & 4165.20 & 68.77 & 0.78 & 0.78 & 0.91 & 16.87 & 0.0130 \\
\hline Plate-10 & 246.06 & 4151.98 & 68.55 & 0.78 & 0.78 & 0.91 & 16.87 & 0.0130 \\
\hline Plate-11 & 246.63 & 4161.70 & 68.71 & 0.78 & 0.78 & 0.91 & 16.87 & 0.0130 \\
\hline Plate-12 & 250.52 & 4227.30 & 69.79 & 0.79 & 0.79 & 0.93 & 16.87 & 0.0130 \\
\hline Plate-13 & 257.95 & 4352.75 & 71.86 & 0.82 & 0.82 & 0.96 & 16.87 & 0.0130 \\
\hline Plate-14 & 270.36 & 4562.16 & 75.32 & 0.86 & 0.86 & 1.00 & 16.87 & 0.0130 \\
\hline Plate-15 & 291.02 & 4910.66 & 81.08 & 0.92 & 0.92 & 1.08 & 16.87 & 0.0130 \\
\hline Plate-16 & 324.10 & 5468.88 & 81.26 & 1.03 & 1.03 & 1.08 & 16.87 & 0.0117 \\
\hline Plate-17 & 374.13 & 6313.18 & 83.38 & 1.18 & 1.18 & 1.11 & 16.87 & 0.0104 \\
\hline Plate-18 & 447.37 & 7549.03 & 74.78 & 1.42 & 1.42 & 0.99 & 16.87 & 0.0078 \\
\hline Plate-19 & 543.26 & 9167.07 & 75.67 & 1.72 & 1.72 & 1.01 & 16.87 & 0.0065 \\
\hline Average & 316.15 & 5334.69 & 75.18 & & & & & \\
\hline
\end{tabular}

\begin{tabular}{|c|c|c|c|c|c|c|c|c|}
\hline \multicolumn{9}{|l|}{ FE-18 } \\
\hline $\begin{array}{l}\text { Plate } \\
\text { ID }\end{array}$ & $(\mathrm{W} / \mathrm{g})$ & (W/cc) & $\left(\mathrm{W} / \mathrm{cm}^{2}\right)$ & $\begin{array}{l}\text { P/A } \\
(W / g)\end{array}$ & $\begin{array}{c}\text { P/A } \\
\text { (W/cc) }\end{array}$ & $\begin{array}{c}\text { P/A } \\
\left(\mathrm{W} / \mathrm{cm}^{2}\right)\end{array}$ & $\begin{array}{c}\text { Density } \\
\text { (g/cc) }\end{array}$ & $\begin{array}{l}\text { Thickness } \\
\text { (in.) }\end{array}$ \\
\hline Plate-1 & 523.11 & 8827.04 & 87.44 & 1.42 & 1.42 & 1.00 & 16.87 & 0.0078 \\
\hline Plate-2 & 420.86 & 7101.62 & 93.80 & 1.14 & 1.14 & 1.07 & 16.87 & 0.0104 \\
\hline Plate-3 & 370.03 & 6243.85 & 92.78 & 1.00 & 1.00 & 1.06 & 16.87 & 0.0117 \\
\hline Plate-4 & 342.28 & 5775.67 & 85.82 & 0.93 & 0.93 & 0.98 & 16.87 & 0.0117 \\
\hline Plate-5 & 317.74 & 5361.55 & 88.52 & 0.86 & 0.86 & 1.01 & 16.87 & 0.0130 \\
\hline
\end{tabular}




$\begin{array}{ccccccccc}\text { Plate-6 } & 304.98 & 5146.26 & 84.96 & 0.83 & 0.83 & 0.97 & 16.87 & 0.0130 \\ \text { Plate-7 } & 294.66 & 4972.13 & 82.09 & 0.80 & 0.80 & 0.94 & 16.87 & 0.0130 \\ \text { Plate-8 } & 288.66 & 4870.95 & 80.42 & 0.78 & 0.78 & 0.92 & 16.87 & 0.0130 \\ \text { Plate-9 } & 286.11 & 4827.84 & 79.71 & 0.78 & 0.78 & 0.91 & 16.87 & 0.0130 \\ \text { Plate-10 } & 286.30 & 4830.97 & 79.76 & 0.78 & 0.78 & 0.91 & 16.87 & 0.0130 \\ \text { Plate-11 } & 288.03 & 4860.24 & 80.24 & 0.78 & 0.78 & 0.92 & 16.87 & 0.0130 \\ \text { Plate-12 } & 293.92 & 4959.62 & 81.88 & 0.80 & 0.80 & 0.93 & 16.87 & 0.0130 \\ \text { Plate-13 } & 303.80 & 5126.33 & 84.64 & 0.82 & 0.82 & 0.97 & 16.87 & 0.0130 \\ \text { Plate-14 } & 319.70 & 5394.56 & 89.06 & 0.87 & 0.87 & 1.02 & 16.87 & 0.0130 \\ \text { Plate-15 } & 345.45 & 5829.12 & 96.24 & 0.94 & 0.94 & 1.10 & 16.87 & 0.0130 \\ \text { Plate-16 } & 386.29 & 6518.21 & 96.85 & 1.05 & 1.05 & 1.11 & 16.87 & 0.0117 \\ \text { Plate-17 } & 447.62 & 7553.11 & 99.76 & 1.21 & 1.21 & 1.14 & 16.87 & 0.0104 \\ \text { Plate-18 } & 535.89 & 9042.64 & 89.58 & 1.45 & 1.45 & 1.02 & 16.87 & 0.0078 \\ \text { Plate-19 } & 654.29 & 11040.59 & 91.14 & 1.77 & 1.77 & 1.04 & 16.87 & 0.0065 \\ \text { Average } & 368.93 & 6225.39 & 87.62 & & & & & \end{array}$

$\begin{array}{ccccccccc}\text { FE-19 } & & & & & & & \\ \text { Plate } & & & & & & \\ \text { ID } & (\mathrm{W} / \mathrm{g}) & (\mathrm{W} / \mathrm{cc}) & \left(\mathrm{W} / \mathrm{cm}^{2}\right) & (\mathrm{W} / \mathrm{g}) & \begin{array}{c}\mathrm{P} / \mathrm{A} \\ (\mathrm{W} / \mathrm{cc})\end{array} & \begin{array}{c}\mathrm{P} / \mathrm{A} \\ \left(\mathrm{W} / \mathrm{cm}^{2}\right)\end{array} & \begin{array}{c}\text { Density } \\ (\mathrm{g} / \mathrm{cc})\end{array} & \begin{array}{c}\text { Thickness } \\ \text { (in.) }\end{array} \\ \text { Plate-1 } & 606.57 & 10235.33 & 101.39 & 1.47 & 1.47 & 1.03 & 16.87 & 0.0078 \\ \text { Plate-2 } & 486.41 & 8207.78 & 108.41 & 1.18 & 1.18 & 1.10 & 16.87 & 0.0104 \\ \text { Plate-3 } & 426.30 & 7193.37 & 106.89 & 1.03 & 1.03 & 1.08 & 16.87 & 0.0117 \\ \text { Plate-4 } & 393.90 & 6646.70 & 98.76 & 0.95 & 0.95 & 1.00 & 16.87 & 0.0117 \\ \text { Plate-5 } & 365.63 & 6169.68 & 101.86 & 0.88 & 0.88 & 1.03 & 16.87 & 0.0130 \\ \text { Plate-6 } & 351.49 & 5931.06 & 97.92 & 0.85 & 0.85 & 0.99 & 16.87 & 0.0130 \\ \text { Plate-7 } & 340.83 & 5751.15 & 94.95 & 0.82 & 0.82 & 0.96 & 16.87 & 0.0130 \\ \text { Plate-8 } & 334.71 & 5647.94 & 93.25 & 0.81 & 0.81 & 0.94 & 16.87 & 0.0130 \\ \text { Plate-9 } & 330.81 & 5582.06 & 92.16 & 0.80 & 0.80 & 0.93 & 16.87 & 0.0130 \\ \text { Plate-10 } & 330.00 & 5568.43 & 91.93 & 0.80 & 0.80 & 0.93 & 16.87 & 0.0130 \\ \text { Plate-11 } & 332.07 & 5603.45 & 92.51 & 0.80 & 0.80 & 0.94 & 16.87 & 0.0130 \\ \text { Plate-12 } & 337.74 & 5699.07 & 94.09 & 0.82 & 0.82 & 0.95 & 16.87 & 0.0130 \\ \text { Plate-13 } & 346.95 & 5854.43 & 96.66 & 0.84 & 0.84 & 0.98 & 16.87 & 0.0130 \\ \text { Plate-14 } & 362.49 & 6116.61 & 100.99 & 0.88 & 0.88 & 1.02 & 16.87 & 0.0130 \\ \text { Plate-15 } & 386.38 & 6519.74 & 107.64 & 0.93 & 0.93 & 1.09 & 16.87 & 0.0130 \\ \text { Plate-16 } & 424.45 & 7162.28 & 106.42 & 1.03 & 1.03 & 1.08 & 16.87 & 0.0117 \\ \text { Plate-17 } & 480.82 & 8113.38 & 107.16 & 1.16 & 1.16 & 1.08 & 16.87 & 0.0104 \\ \text { Plate-18 } & 559.00 & 9432.58 & 93.44 & 1.35 & 1.35 & 0.95 & 16.87 & 0.0078 \\ \text { Plate-19 } & 658.04 & 11103.84 & 91.66 & 1.59 & 1.59 & 0.93 & 16.87 & 0.0065 \\ \text { Average } & 413.40 & 6975.73 & 98.85 & & & & & \end{array}$

$\begin{array}{ccccccccc}\begin{array}{c}\text { FE-20 } \\ \text { Plate }\end{array} & & & & & & & \\ \text { ID } & (\mathrm{W} / \mathrm{g}) & (\mathrm{W} / \mathrm{cc}) & \left(\mathrm{W} / \mathrm{cm}^{2}\right) & (\mathrm{W} / \mathrm{g}) & \begin{array}{c}\mathrm{P} / \mathrm{A} \\ (\mathrm{W} / \mathrm{cc})\end{array} & \begin{array}{c}\mathrm{P} / \mathrm{A} \\ \left(\mathrm{W} / \mathrm{cm}^{2}\right)\end{array} & \begin{array}{c}\text { Density } \\ (\mathrm{g} / \mathrm{cc})\end{array} & \begin{array}{c}\text { Thickness } \\ \text { (in.) }\end{array} \\ \text { Plate-1 } & 605.37 & 10215.08 & 101.19 & 1.46 & 1.46 & 0.96 & 16.87 & 0.0078 \\ \text { Plate-2 } & 492.78 & 8315.17 & 109.83 & 1.19 & 1.19 & 1.04 & 16.87 & 0.0104 \\ \text { Plate-3 } & 438.82 & 7404.72 & 110.03 & 1.06 & 1.06 & 1.04 & 16.87 & 0.0117\end{array}$




$\begin{array}{ccccccccc}\text { Plate-4 } & 410.39 & 6924.91 & 102.90 & 0.99 & 0.99 & 0.97 & 16.87 & 0.0117 \\ \text { Plate-5 } & 384.85 & 6493.94 & 107.21 & 0.93 & 0.93 & 1.01 & 16.87 & 0.0130 \\ \text { Plate-6 } & 372.54 & 6286.20 & 103.79 & 0.90 & 0.90 & 0.98 & 16.87 & 0.0130 \\ \text { Plate-7 } & 363.44 & 6132.76 & 101.25 & 0.88 & 0.88 & 0.96 & 16.87 & 0.0130 \\ \text { Plate-8 } & 359.16 & 6060.55 & 100.06 & 0.87 & 0.87 & 0.95 & 16.87 & 0.0130 \\ \text { Plate-9 } & 357.30 & 6029.06 & 99.54 & 0.86 & 0.86 & 0.94 & 16.87 & 0.0130 \\ \text { Plate-10 } & 358.68 & 6052.39 & 99.92 & 0.87 & 0.87 & 0.94 & 16.87 & 0.0130 \\ \text { Plate-11 } & 362.52 & 6117.17 & 100.99 & 0.88 & 0.88 & 0.95 & 16.87 & 0.0130 \\ \text { Plate-12 } & 369.06 & 6227.61 & 102.82 & 0.89 & 0.89 & 0.97 & 16.87 & 0.0130 \\ \text { Plate-13 } & 380.03 & 6412.61 & 105.87 & 0.92 & 0.92 & 1.00 & 16.87 & 0.0130 \\ \text { Plate-14 } & 397.76 & 6711.89 & 110.81 & 0.96 & 0.96 & 1.05 & 16.87 & 0.0130 \\ \text { Plate-15 } & 423.95 & 7153.73 & 118.11 & 1.03 & 1.03 & 1.12 & 16.87 & 0.0130 \\ \text { Plate-16 } & 466.30 & 7868.42 & 116.92 & 1.13 & 1.13 & 1.10 & 16.87 & 0.0117 \\ \text { Plate-17 } & 527.28 & 8897.45 & 117.52 & 1.28 & 1.28 & 1.11 & 16.87 & 0.0104 \\ \text { Plate-18 } & 611.12 & 10312.15 & 102.15 & 1.48 & 1.48 & 0.97 & 16.87 & 0.0078 \\ \text { Plate-19 } & 715.03 & 12065.45 & 99.60 & 1.73 & 1.73 & 0.94 & 16.87 & 0.0065 \\ \text { Average } & 441.92 & 7456.91 & 105.82 & & & & & \end{array}$


Table A-4. Averaged fuel azimuthal fission power density local to average ratio (L2AR).

\begin{tabular}{|c|c|c|c|c|c|c|c|c|c|c|}
\hline FE-16 & $A Z-1$ & AZ-2 & AZ-3 & AZ-4 & AZ-5 & AZ-6 & AZ-7 & AZ-8 & AZ-9 & $A Z-10$ \\
\hline Plate-1 & 0.00 & 1.04 & 0.98 & 0.98 & 0.96 & 0.97 & 0.98 & 1.02 & 1.07 & 0.00 \\
\hline Plate-2 & 1.09 & 1.01 & 0.95 & 0.93 & 0.93 & 0.93 & 0.95 & 0.98 & 1.04 & 1.17 \\
\hline Plate-3 & 1.13 & 1.00 & 0.94 & 0.93 & 0.90 & 0.92 & 0.95 & 0.96 & 1.06 & 1.22 \\
\hline Plate-4 & 1.14 & 0.98 & 0.95 & 0.93 & 0.90 & 0.92 & 0.94 & 0.96 & 1.05 & 1.22 \\
\hline Plate-5 & 1.13 & 0.99 & 0.94 & 0.93 & 0.90 & 0.91 & 0.94 & 0.98 & 1.04 & 1.23 \\
\hline Plate-6 & 1.17 & 0.99 & 0.96 & 0.91 & 0.93 & 0.90 & 0.91 & 0.96 & 1.03 & 1.23 \\
\hline Plate-7 & 1.17 & 1.01 & 0.96 & 0.93 & 0.91 & 0.91 & 0.92 & 0.96 & 1.03 & 1.20 \\
\hline Plate-8 & 1.15 & 1.02 & 0.95 & 0.92 & 0.91 & 0.91 & 0.90 & 0.98 & 1.04 & 1.21 \\
\hline Plate-9 & 1.16 & 1.02 & 0.94 & 0.93 & 0.92 & 0.92 & 0.92 & 0.97 & 1.02 & 1.20 \\
\hline Plate-10 & 1.18 & 1.01 & 0.96 & 0.94 & 0.92 & 0.91 & 0.91 & 0.96 & 1.03 & 1.19 \\
\hline Plate-11 & 1.20 & 1.02 & 0.96 & 0.94 & 0.93 & 0.91 & 0.91 & 0.94 & 1.00 & 1.20 \\
\hline Plate-12 & 1.23 & 1.03 & 0.95 & 0.95 & 0.92 & 0.92 & 0.92 & 0.92 & 0.99 & 1.18 \\
\hline Plate-13 & 1.22 & 1.06 & 0.98 & 0.94 & 0.92 & 0.91 & 0.90 & 0.90 & 0.99 & 1.17 \\
\hline Plate-14 & 1.27 & 1.08 & 0.99 & 0.94 & 0.94 & 0.90 & 0.87 & 0.90 & 0.96 & 1.16 \\
\hline Plate-15 & 1.30 & 1.08 & 1.01 & 0.97 & 0.93 & 0.89 & 0.87 & 0.87 & 0.94 & 1.14 \\
\hline Plate-16 & 1.29 & 1.11 & 1.05 & 0.98 & 0.95 & 0.87 & 0.85 & 0.87 & 0.92 & 1.10 \\
\hline Plate-17 & 1.35 & 1.15 & 1.10 & 1.02 & 0.95 & 0.87 & 0.82 & 0.82 & 0.88 & 1.04 \\
\hline Plate-18 & 1.40 & 1.23 & 1.13 & 1.07 & 0.97 & 0.83 & 0.78 & 0.77 & 0.82 & 1.00 \\
\hline Plate-19 & 1.43 & 1.30 & 1.21 & 1.11 & 0.98 & 0.84 & 0.74 & 0.71 & 0.77 & 0.89 \\
\hline FE-17 & $A Z-1$ & $A Z-2$ & $A Z-3$ & $A Z-4$ & $A Z-5$ & AZ-6 & $A Z-7$ & AZ-8 & $A Z-9$ & $A Z-10$ \\
\hline Plate-1 & 0.00 & 1.02 & 0.98 & 0.96 & 0.97 & 0.98 & 0.99 & 1.03 & 1.07 & 0.00 \\
\hline Plate-2 & 1.10 & 0.99 & 0.94 & 0.92 & 0.93 & 0.94 & 0.95 & 0.99 & 1.06 & 1.18 \\
\hline Plate-3 & 1.12 & 0.99 & 0.92 & 0.92 & 0.91 & 0.93 & 0.96 & 0.97 & 1.06 & 1.22 \\
\hline Plate-4 & 1.12 & 0.99 & 0.93 & 0.89 & 0.91 & 0.91 & 0.95 & 0.98 & 1.08 & 1.25 \\
\hline Plate-5 & 1.11 & 0.99 & 0.92 & 0.88 & 0.91 & 0.90 & 0.94 & 0.98 & 1.09 & 1.28 \\
\hline Plate-6 & 1.11 & 0.98 & 0.92 & 0.89 & 0.91 & 0.91 & 0.93 & 0.99 & 1.08 & 1.29 \\
\hline Plate-7 & 1.12 & 0.98 & 0.92 & 0.90 & 0.89 & 0.92 & 0.93 & 0.97 & 1.10 & 1.28 \\
\hline Plate-8 & 1.09 & 0.97 & 0.91 & 0.89 & 0.90 & 0.93 & 0.94 & 0.98 & 1.10 & 1.28 \\
\hline Plate-9 & 1.10 & 0.96 & 0.92 & 0.90 & 0.90 & 0.93 & 0.94 & 0.98 & 1.08 & 1.29 \\
\hline Plate-10 & 1.07 & 0.95 & 0.91 & 0.91 & 0.91 & 0.91 & 0.96 & 0.99 & 1.09 & 1.30 \\
\hline Plate-11 & 1.07 & 0.93 & 0.91 & 0.90 & 0.91 & 0.93 & 0.95 & 1.00 & 1.10 & 1.29 \\
\hline Plate-12 & 1.05 & 0.94 & 0.91 & 0.91 & 0.91 & 0.93 & 0.96 & 0.99 & 1.09 & 1.31 \\
\hline Plate-13 & 1.05 & 0.93 & 0.91 & 0.89 & 0.92 & 0.92 & 0.97 & 1.01 & 1.09 & 1.31 \\
\hline Plate-14 & 1.03 & 0.91 & 0.90 & 0.90 & 0.93 & 0.94 & 0.97 & 1.01 & 1.10 & 1.31 \\
\hline Plate-15 & 1.01 & 0.89 & 0.90 & 0.91 & 0.94 & 0.95 & 0.98 & 1.02 & 1.10 & 1.30 \\
\hline Plate-16 & 0.98 & 0.90 & 0.90 & 0.92 & 0.94 & 0.99 & 1.01 & 1.03 & 1.08 & 1.27 \\
\hline Plate-17 & 0.95 & 0.89 & 0.90 & 0.95 & 0.96 & 0.99 & 1.01 & 1.05 & 1.08 & 1.24 \\
\hline Plate-18 & 0.90 & 0.88 & 0.92 & 0.95 & 0.97 & 1.00 & 1.04 & 1.06 & 1.09 & 1.21 \\
\hline Plate-19 & 0.85 & 0.87 & 0.90 & 0.96 & 1.00 & 1.02 & 1.06 & 1.07 & 1.12 & 1.16 \\
\hline FE-18 & $A Z-1$ & AZ-2 & AZ-3 & AZ-4 & AZ-5 & AZ-6 & AZ-7 & AZ-8 & AZ-9 & $A Z-10$ \\
\hline Plate-1 & 0.00 & 0.99 & 0.97 & 0.96 & 0.96 & 0.97 & 1.00 & 1.04 & 1.10 & 0.00 \\
\hline Plate-2 & 1.04 & 0.98 & 0.92 & 0.92 & 0.91 & 0.93 & 0.95 & 1.01 & 1.11 & 1.23 \\
\hline Plate-3 & 1.09 & 0.97 & 0.92 & 0.90 & 0.92 & 0.92 & 0.95 & 0.99 & 1.10 & 1.24 \\
\hline Plate-4 & 1.10 & 0.97 & 0.92 & 0.89 & 0.90 & 0.92 & 0.94 & 0.98 & 1.09 & 1.28 \\
\hline
\end{tabular}




\begin{tabular}{|c|c|c|c|c|c|c|c|c|c|c|}
\hline Plate-5 & 1.11 & 0.98 & 0.92 & 0.90 & 0.90 & 0.91 & 0.92 & 0.99 & 1.09 & 1.29 \\
\hline Plate-6 & 1.10 & 0.98 & 0.90 & 0.89 & 0.89 & 0.91 & 0.94 & 0.99 & 1.09 & 1.30 \\
\hline Plate-7 & 1.11 & 0.97 & 0.91 & 0.90 & 0.90 & 0.91 & 0.93 & 0.98 & 1.09 & 1.30 \\
\hline Plate-8 & 1.12 & 0.96 & 0.91 & 0.90 & 0.89 & 0.90 & 0.94 & 0.98 & 1.09 & 1.30 \\
\hline Plate-9 & 1.10 & 0.96 & 0.92 & 0.91 & 0.90 & 0.91 & 0.94 & 1.00 & 1.08 & 1.28 \\
\hline Plate-10 & 1.11 & 0.96 & 0.90 & 0.89 & 0.91 & 0.93 & 0.95 & 0.99 & 1.08 & 1.29 \\
\hline Plate-11 & 1.09 & 0.96 & 0.91 & 0.90 & 0.90 & 0.91 & 0.95 & 1.00 & 1.08 & 1.29 \\
\hline Plate-12 & 1.09 & 0.94 & 0.90 & 0.92 & 0.92 & 0.93 & 0.96 & 0.98 & 1.09 & 1.28 \\
\hline Plate-13 & 1.08 & 0.94 & 0.91 & 0.90 & 0.92 & 0.94 & 0.97 & 0.99 & 1.07 & 1.28 \\
\hline Plate-14 & 1.06 & 0.94 & 0.91 & 0.91 & 0.93 & 0.95 & 0.98 & 0.99 & 1.07 & 1.26 \\
\hline Plate-15 & 1.05 & 0.93 & 0.90 & 0.91 & 0.93 & 0.96 & 0.98 & 1.01 & 1.06 & 1.26 \\
\hline Plate-16 & 1.04 & 0.93 & 0.91 & 0.92 & 0.94 & 0.96 & 0.99 & 1.02 & 1.06 & 1.24 \\
\hline Plate-17 & 1.01 & 0.93 & 0.90 & 0.91 & 0.96 & 0.97 & 1.01 & 1.03 & 1.07 & 1.21 \\
\hline Plate-18 & 0.99 & 0.91 & 0.91 & 0.93 & 0.96 & 1.00 & 1.01 & 1.02 & 1.08 & 1.19 \\
\hline Plate-19 & 0.94 & 0.90 & 0.92 & 0.95 & 0.97 & 1.02 & 1.03 & 1.06 & 1.08 & 1.14 \\
\hline FE-19 & $A Z-1$ & AZ-2 & AZ-3 & AZ-4 & AZ-5 & AZ-6 & AZ-7 & AZ-8 & AZ-9 & $A Z-10$ \\
\hline Plate-1 & 0.00 & 1.08 & 1.01 & 0.96 & 0.97 & 0.98 & 0.98 & 0.99 & 1.04 & 0.00 \\
\hline Plate-2 & 1.15 & 1.05 & 0.96 & 0.93 & 0.92 & 0.92 & 0.93 & 0.97 & 1.03 & 1.14 \\
\hline Plate-3 & 1.17 & 1.04 & 0.97 & 0.92 & 0.91 & 0.91 & 0.93 & 0.97 & 1.03 & 1.16 \\
\hline Plate-4 & 1.21 & 1.04 & 0.94 & 0.92 & 0.91 & 0.91 & 0.92 & 0.95 & 1.03 & 1.17 \\
\hline Plate-5 & 1.20 & 1.05 & 0.94 & 0.93 & 0.90 & 0.90 & 0.92 & 0.95 & 1.02 & 1.19 \\
\hline Plate-6 & 1.20 & 1.02 & 0.95 & 0.92 & 0.89 & 0.91 & 0.93 & 0.97 & 1.04 & 1.19 \\
\hline Plate-7 & 1.20 & 1.02 & 0.93 & 0.92 & 0.92 & 0.92 & 0.93 & 0.95 & 1.02 & 1.19 \\
\hline Plate-8 & 1.18 & 1.02 & 0.95 & 0.92 & 0.92 & 0.91 & 0.92 & 0.96 & 1.03 & 1.17 \\
\hline Plate-9 & 1.18 & 1.02 & 0.95 & 0.94 & 0.93 & 0.91 & 0.94 & 0.95 & 1.01 & 1.18 \\
\hline Plate-10 & 1.18 & 1.01 & 0.96 & 0.94 & 0.93 & 0.92 & 0.93 & 0.96 & 1.02 & 1.17 \\
\hline Plate-11 & 1.18 & 1.01 & 0.95 & 0.93 & 0.92 & 0.93 & 0.93 & 0.96 & 1.02 & 1.16 \\
\hline Plate-12 & 1.18 & 1.01 & 0.96 & 0.94 & 0.93 & 0.94 & 0.94 & 0.96 & 1.00 & 1.14 \\
\hline Plate-13 & 1.17 & 1.01 & 0.97 & 0.95 & 0.94 & 0.94 & 0.94 & 0.95 & 1.00 & 1.13 \\
\hline Plate-14 & 1.19 & 1.02 & 0.98 & 0.96 & 0.95 & 0.94 & 0.94 & 0.95 & 0.97 & 1.09 \\
\hline Plate-15 & 1.20 & 1.04 & 0.99 & 0.96 & 0.96 & 0.95 & 0.93 & 0.94 & 0.96 & 1.08 \\
\hline Plate-16 & 1.18 & 1.06 & 1.01 & 0.99 & 0.97 & 0.95 & 0.93 & 0.92 & 0.93 & 1.04 \\
\hline Plate-17 & 1.20 & 1.08 & 1.04 & 1.01 & 1.00 & 0.97 & 0.92 & 0.90 & 0.90 & 0.99 \\
\hline Plate-18 & 1.21 & 1.11 & 1.07 & 1.05 & 1.03 & 0.98 & 0.91 & 0.88 & 0.85 & 0.93 \\
\hline Plate-19 & 1.21 & 1.14 & 1.11 & 1.09 & 1.04 & 0.99 & 0.92 & 0.85 & 0.81 & 0.84 \\
\hline FE-20 & $A Z-1$ & AZ-2 & AZ-3 & AZ-4 & AZ-5 & AZ-6 & AZ-7 & AZ-8 & AZ-9 & $A Z-10$ \\
\hline Plate-1 & 0.00 & 1.04 & 1.00 & 0.98 & 0.97 & 0.97 & 0.98 & 1.00 & 1.05 & 0.00 \\
\hline Plate-2 & 1.11 & 1.02 & 0.96 & 0.94 & 0.92 & 0.93 & 0.95 & 0.98 & 1.05 & 1.15 \\
\hline Plate-3 & 1.14 & 1.03 & 0.96 & 0.91 & 0.92 & 0.92 & 0.93 & 0.98 & 1.05 & 1.17 \\
\hline Plate-4 & 1.14 & 1.01 & 0.95 & 0.92 & 0.92 & 0.91 & 0.94 & 0.96 & 1.04 & 1.20 \\
\hline Plate-5 & 1.16 & 1.00 & 0.95 & 0.92 & 0.91 & 0.92 & 0.93 & 0.97 & 1.05 & 1.21 \\
\hline Plate-6 & 1.14 & 1.01 & 0.94 & 0.93 & 0.91 & 0.92 & 0.93 & 0.97 & 1.05 & 1.21 \\
\hline Plate-7 & 1.14 & 0.99 & 0.94 & 0.93 & 0.92 & 0.93 & 0.95 & 0.98 & 1.03 & 1.20 \\
\hline Plate-8 & 1.13 & 1.00 & 0.94 & 0.92 & 0.92 & 0.91 & 0.94 & 0.97 & 1.05 & 1.21 \\
\hline Plate-9 & 1.11 & 0.98 & 0.95 & 0.92 & 0.94 & 0.93 & 0.97 & 0.98 & 1.04 & 1.19 \\
\hline Plate-10 & 1.12 & 0.99 & 0.94 & 0.92 & 0.94 & 0.93 & 0.95 & 0.99 & 1.04 & 1.18 \\
\hline Plate-11 & 1.11 & 0.98 & 0.94 & 0.94 & 0.92 & 0.93 & 0.96 & 0.98 & 1.04 & 1.19 \\
\hline Plate-12 & 1.09 & 0.98 & 0.94 & 0.93 & 0.94 & 0.95 & 0.97 & 0.99 & 1.03 & 1.19 \\
\hline Plate-13 & 1.10 & 0.97 & 0.94 & 0.93 & 0.93 & 0.94 & 0.97 & 0.99 & 1.03 & 1.20 \\
\hline
\end{tabular}




$\begin{array}{lllllllllll}\text { Plate-14 } & 1.09 & 0.96 & 0.94 & 0.93 & 0.93 & 0.95 & 0.96 & 1.00 & 1.05 & 1.20 \\ \text { Plate-15 } & 1.06 & 0.96 & 0.94 & 0.93 & 0.94 & 0.96 & 0.98 & 0.99 & 1.05 & 1.19 \\ \text { Plate-16 } & 1.05 & 0.96 & 0.91 & 0.93 & 0.95 & 0.97 & 0.99 & 1.01 & 1.05 & 1.18 \\ \text { Plate-17 } & 1.03 & 0.94 & 0.92 & 0.91 & 0.96 & 0.97 & 1.00 & 1.02 & 1.06 & 1.19 \\ \text { Plate-18 } & 1.01 & 0.93 & 0.91 & 0.92 & 0.95 & 0.98 & 1.02 & 1.03 & 1.07 & 1.18 \\ \text { Plate-19 } & 0.98 & 0.91 & 0.91 & 0.93 & 0.96 & 0.99 & 1.03 & 1.06 & 1.09 & 1.15\end{array}$


Table A-5. FE-18 Axial local to average ratio.

$\begin{array}{ccccc}\begin{array}{c}\text { Axial } \\ \text { position } \\ \text { (in.) }\end{array} & \begin{array}{c}\text { HEU } \\ \text { Case-A }\end{array} & \begin{array}{c}\text { LEU } \\ \text { U10Mo }\end{array} & \begin{array}{c}\text { LEU } \\ \text { U10Mo }\end{array} & \begin{array}{c}\text { Averaged } \\ \text { axial }\end{array} \\ \begin{array}{c}\text { Case-D } 23.25 \\ \text { profile }\end{array} \\ 21.75 & 0.36 & 0.22 & 0.22 & 0.26 \\ 20.25 & 0.39 & 0.27 & 0.28 & 0.31 \\ 18.75 & 0.51 & 0.41 & 0.42 & 0.45 \\ 17.25 & 0.74 & 0.56 & 0.56 & 0.58 \\ 15.75 & 0.84 & 0.68 & 0.68 & 0.70 \\ 14.25 & 0.93 & 0.89 & 0.79 & 0.81 \\ 12.75 & 1.01 & 0.99 & 1.00 & 0.91 \\ 11.25 & 1.09 & 1.08 & 1.08 & 1.08 \\ 9.75 & 1.16 & 1.15 & 1.16 & 1.16 \\ 8.25 & 1.24 & 1.21 & 1.23 & 1.23 \\ 6.75 & 1.28 & 1.27 & 1.29 & 1.28 \\ 5.25 & 1.33 & 1.33 & 1.34 & 1.33 \\ 3.75 & 1.36 & 1.38 & 1.38 & 1.37 \\ 2.25 & 1.38 & 1.40 & 1.40 & 1.39 \\ 0.75 & 1.40 & 1.42 & 1.42 & 1.42 \\ -0.75 & 1.40 & 1.44 & 1.41 & 1.42 \\ -2.25 & 1.38 & 1.43 & 1.41 & 1.41 \\ -3.75 & 1.36 & 1.42 & 1.40 & 1.39 \\ -5.25 & 1.35 & 1.39 & 1.38 & 1.37 \\ -6.75 & 1.31 & 1.35 & 1.36 & 1.34 \\ -8.25 & 1.25 & 1.30 & 1.31 & 1.29 \\ -9.75 & 1.21 & 1.25 & 1.26 & 1.24 \\ -11.25 & 1.13 & 1.19 & 1.18 & 1.17 \\ -12.75 & 1.07 & 1.11 & 1.10 & 1.09 \\ -14.25 & 0.98 & 1.02 & 1.02 & 1.01 \\ -15.75 & 0.89 & 0.93 & 0.93 & 0.92 \\ -17.25 & 0.79 & 0.83 & 0.83 & 0.82 \\ -18.75 & 0.70 & 0.72 & 0.71 & 0.71 \\ -20.25 & 0.60 & 0.60 & 0.59 & 0.60 \\ -21.75 & 0.48 & 0.49 & 0.49 & 0.49 \\ -23.25 & 0.47 & 0.48 & 0.46 & 0.47\end{array}$

